\title{
Disorders of Neuronal Migration
}

\author{
Peter G. Barth
}

\begin{abstract}
Neuronal migration constitutes one of the major processes by which the central nervous system takes shape. Detailed knowledge about this important process now exists for different brain regions in rodent and monkey models as well as in the human. In the human, distinct genetic, chromosomal and environmental causes are known that affect neuronal migration, often in a morphologically distinct pattern, but the underlying pathological mechanisms are largely unknown. This review is intended to integrate our basic knowledge of the field with the accumulated intelligence on a large number of disorders and syndromes that represent the human part of the story.

RÉSUMÉ: Pertubations de la migration neuronale La migration neuronale constitue un des processus les plus importants par lequel le système nerveux central est façonné. Nous possédons actuellement des connaissances détaillées sur ce processus important dans différentes régions du cerveau de modèles animaux (rongeurs et singes) ainsi que chez l'humain. Chez l'humain, des causes génétiques, chromosomiques et environnementales distinctes sont connues comme affectant la migration neuronale, donnant lieu à des patterns morphologiques souvent distincts; les mécanismes pathologiques sous-jacents sont pour la plupart inconnus. Dans la présente revue, nous désirons intégrer nos connaissances de base dans ce domaine avec les données accumulées au sujet d'un grand nombre d'affections et de syndromes représentant leur contrepartie chez l'humain.
\end{abstract}

Can. J. Neurol. Sci. 1987:14:1-16

After the closing of the neural tube and the formation of the telencephalic vesicles, neuronal migration is the main process by which topical differentiation within the brain is effected. By this process many billions of newly generated neural cells are addressed to their proper position mainly in nuclear masses or in the cerebral and cerebellar cortices. General or topical loss of control over this process is generally called neuronal migration disorder (abbreviated NMD). NMD will result in either cell death or improper positioning of functional cell groups. This in turn will result in failing connections or improper wiring (misconnections) responsible for functional deficiencies and epilepsy. The clinical relevance of NMD is highlighted by an increasing body of literature on a number of specific clinical entities, either inherited or prenatally acquired, and by the increasing resolution of imaging techniques by which NMD can be detected or at least suspected. Basic understanding of neuronal migration, mainly by morphological observations on rodent embryos, either normal or belonging to strains harboring inherited NMD, has increased substantially over the past twenty years; the understanding of the process in biochemical terms is emerging. NMD in the human embryo-fetus may arise from monogenetic (metabolic), chromosomal, hypoxic-ischemic and toxic-environmental causes. The morphological patterns involved are not of a monotonous kind, but vary according to the cause or agent, the affected site and the gestational age when the abnormality takes effect. This review is concerned with NMD that affects the neocortex, the cerebellum and the brainstem. The neural crest and its disorders will not be included because extensive reviews on this topic have appeared elsewhere.

\section{The Process of Neuronal Migration in the Brain} Neocortex

The ventricular and subventricular zones of the telencephalon provide the neuronal and glial stem cells and from here migration to the cortical plate, the future neocortex, starts in a radial centrifugal fashion. The migration of young neurons is guided from an early stage by a system of radial glial fibers that span the width of the thickening telencephalon. ${ }^{1}$ In the human fetus this process takes place for the greater part between 7 and 16 weeks gestational age. The perikarya of the radial glial cells are in the ventricular and subventricular zones. Cells of glial and neuronal lineage (the former marked by GFAP-staining) could be separated as different proliferative lines within the ventricular epithelium in monkey fetus. ${ }^{2}$ The layers of the neocortex are generally laid down in an inside-out fashion, ' e.g. layer III neurons arriving before layer II neurons which means that later migration waves have to pass earlier migration

From the Departments of Neurology and Pediatrics (Pediatric Neurology), University Hospital of Amsterdam and the Department of Neuropathology, Free University Hospital, Amsterdam, The Netherlands.

Reprint requests to: P.G. Barth, Pediatric Neurology, Room G8-207, University Hospital of Amsterdam, Meibergdreef 9, 1105 AZ Amsterdam, The Netherlands. 
waves. ${ }^{1,3,4}$ As an exception to this rule it has been suggested that neurons of layer I, the giant Cajal-Retzius neurons and layer VIb, the lower part of layer VI are laid down as a single neuronal network, the primordial plexiform layer, in analogy to the amphibian neocortex and prior to the other layers in mammals. This primordial plexiform layer is thought to provide a framework for the successive migration waves as these become sandwiched between the upper and the lower part of this structure. $^{5}$

The radial glial system was described early in this century by Ramón y Cajal, who used the Golgi technique. ${ }^{6}$ Revival of this technique combined with transmission electron microscopy ${ }^{7}$ and the application of GFAP-staining ${ }^{8}$ facilitated the discovery and detailed description in the monkey fetus. By the use of the same methods demonstration was possible in the human fetus. ${ }^{9.10}$ Choi and Lapham ${ }^{10}$ noted the persistence of radial glia in the human telencephalon beyond 16 weeks, raising the possibility that migration does not end sharply at this time. The date of the latest arriving neurons in the human neocortex has not been decided yet. However important the radial glial system may be in providing guidance to migrating neurons, other organizing principles cannot be excluded, such as the thalamo-cortical afferents, that already exist before migration to the cortical plate starts.

Differentiation into neuronal classes characteristic of each cortical layer follows on the completion of migration. This differentiation effects both the shape of the perikaryon (pyramidal and non-pyramidal) and its connections. The commitment of a neuron to differentiate into a certain morphological class appears to depend mostly on the order in which it is generated, rather than on its final position within the neocortex. The best available evidence is the murine reeler mutant that harbors an inherited NMD which specifically affects the intracortical part of the migration trajectory for pyramidal neurons. In the case of this mutant the perikaryal shapes characteristic of each layer are established in spite of faulty positioning. ${ }^{11-15}$ After the completion of the migration process the radial glia disappears. In part these cells appear to transform into astrocytes and ependymal cells. ${ }^{16}$ Evidence obtained from the study of fetal human spinal cord suggests that transformation into oligodendroglial cells is also a possibility. ${ }^{17-19}$ One structure belonging to the emerging human neocortex, the subpial layer of Ranke, ${ }^{20}$ still awaits elucidation. It occupies the superior part of the molecular layer in the form of several layers of apparent germinal cells from the end of the fourth fetal month in the human until the end of gestation. It was described by Ranke ${ }^{20}$ who credits His with the discovery. The structure is only transiently present in some gyrencephalic mammals including man.

\section{The cerebellum}

In the cerebellum the mode of migration is different for Purkinje cells and granule cells. The former migrate at 9-10 weeks, but the precise mode is unknown. The granule cells (and possibly the stellate- and basket cells as well) are derived from the external granule cell layer, emerging at 10-11 weeks from the edges of the rhombencephalic roof near the lateral recess of the fourth ventricle, a place where the proximity of the ventricular zone, the starting place of neural cell generation, to the pial surface is very close. From here the future external granule cells start to cover the whole cerebellar surface under the pia. From here postmitotic external granule cells migrate inward and pass the Purkinje cells to form the internal granular layer. ${ }^{21}$ In doing so they leave a neurite in the molecular layer that grows out to form the parallel fibers.' In this way the external granular layer (and the corpus pontobulbare to be described below) is an exception to the pattern of migration that usually proceeds from the center of the neuraxis in a centrifugal fashion. The guidance for the migrating granule cells in the cerebellum is provided by the vertically oriented Bergmann glial fibers that override the molecular layer with endfeet at the pial surface. ${ }^{22}$ The glial cerebellar guidance system has been confirmed in the human fetus. ${ }^{23}$ The external granular layer is the latest germinal layer in the brain to disappear, involution starting at 9 months postpartum.

\section{Pontine and olivary nuclei}

An important role is played here by the corpus pontobulbare a transient structure near the lateral recess of the fourth ventricle. It represents an accumulation of dividing stem cells located ventrally and anteriorly to the lateral recess where the distance between the ventricular epithelium and the pia is minimal. From here postmitotic neurons destined for the olivary-, arcuateand pontine nuclei migrate to their final destinations. This represents another instance of a superficially located germinal center. ${ }^{24-27}$ The original site of the cells giving rise to the olivary nuclei is relevant to the location of olivary heterotopia to be described below.

\section{New developments}

Research on the process of neuronal migration at the molecular level has only begun. Logic requires that cell-cell recognition especially neuron-glia recognition forms an essential part of the story. Much has been gained already from the study of the autosomal recessive murine weaver mutant. In homozygous weaver granule cells in the cerebellum completely fail to reach the internal granule layer and Bergmann glia is severely deficient. Large numbers of arrested granule cells die. Heterozygous weaver shows mildly disturbed migration and abnormal Bergmann glial cells with thickened and irregular processes ${ }^{28}$ To disentangle the respective role of granule cells and Bergmann glial cells chimaeras were produced carrying both heterozygous weaver and normal cell lines that could be distinguished by an enzymatic histochemical marker. ${ }^{29}$ In this study it was shown that granule cells carrying the weaver gene were unable to migrate even in the presence of Bergmann cells, whereas the genetically normal granule cells migrated normally. In another study dissociated cultures of weaver cerebellar cells showed both glial and granule cells to be abnormal compared to controls, the former showing stunted growth and the latter dying prematurely. The culture study further showed the existence of two types of astroglia, an extended type resembling Bergmann-glia and a stellate type reminescent of the internal granular layer. Agglutination studies with a number of lectins demonstrated abnormal surface properties of the cerebellar cells of the weaver mutant. ${ }^{30}$

Present evidence recently reviewed ${ }^{31}$ suggests that the trophic influence of neurons and astroglia is bidirectional. The experience with the weaver mutant highlights a relation between NMD and cell death that may have significance for the understanding of human pathology. The coincidence of microencephaly and NMD in a high proportion of human cases might in part be explained by similar mechanisms. A recently discovered class of tissue specific glycoproteins called cell adhesion molecules 
(CAM), some of them transiently present on the surface of embryonic cells, are now being explored for their role in embryonic shaping processes including neuronal migration. ${ }^{32}$ Special interest is focused on a CAM that promote heterotypic (different cell type) adhesion between neuron and glial cell so-called $\mathrm{Ng}$-CAM (neuron-glia), which has been isolated from chick brain. Beside CAM substrate adhesion molecules (SAM) have been studied intensively. These molecules that differ from CAM include laminin, fibronectin and type IV procollagen. These molecules play a key role in the migration of embryonic cells outside the neuraxis such as neural crest cells but their role within the neuraxis has yet to be decided. ${ }^{33}$ The migration of cell processes (neurites) prior to the formation of synapses may have some relevance to the migration of whole cell bodies in terms of the process of cell-cell recognition. Studies with invertebrate species of grasshopper and drosophila have proved the existence of highly specific recognition markers on neuronal cell bodies that provide cues to the exploring growth cone and filopodia of an outgrowing neurite. ${ }^{34-36}$

Another interesting field possibly related to neuronal migration is polyamine metabolism. Polyamines are low-molecularweight amines, called spermine and spermidine and their precursor putrescine. These ubiquitous compounds are intimately linked to DNA synthesis and probably also to the synthesis of microtubules and microfilaments. ${ }^{37} \mathrm{~A}$ potent inhibitor of polyamine synthesis, $\alpha$-difluoromethylornithine (DFMO) exists. When administered to rats between postnatal days 1-21 cerebellar hypoplasia results, combined with entrapment of migrating cerebellar granule cells in the molecular layer. ${ }^{38}$

Clinical experience has focused attention on the possible roles of peroxisomal and mitochondrial fatty acid oxidation in the genesis of inherited NMD such as present in Zellweger (cerebro-hepato-renal) syndrome ${ }^{39}$ and warty dysplasia with multiple acyl-coA dehydrogenase deficiency, ${ }^{40,41}$ to be discussed below. Very recently somatomedin IGF II has become implicated in enhanced brain growth (megalencephaly) and NMD pointing to another field related to brain growth as well as neuronal migration. ${ }^{42}$

\section{Classification of Neuronal Migration Disorders BY MORPHOLOGY}

A general classification of NMD is presented in Table 1. A relatively large number of cases with NMD harbors more as one type listed in Table 1. Some types of NMD listed are often seen together e.g. type I agyria and olivary heterotopia or

Table 1: Classification of neuronal migration disorders by morphological criteria

\begin{tabular}{ll}
\hline \hline 1. Agyria/pachygyria & $\begin{array}{l}\text { type I } \\
\text { type II } \\
\text { unsettled }\end{array}$ \\
$\begin{array}{l}\text { 2. Microgyria (s. polymicrogyria, s. micropolygyria) } \\
\text { four layered } \\
\text { unlayered } \\
\text { fused microgyri }\end{array}$ \\
$\begin{array}{ll}\text { 3. Verrucous dysplasi of the neocortex } & \text { Intra-axial neuronal heterotopia in the forebrain } \\
\text { 5. Leptomeningeal heterotopia of neural tissue } & \\
\text { 6. Cerebellar cortical dysplasias and heterotopia } & \\
\text { 7. Olivary heterotopia } & \end{array}$ \\
8. Schizencephaly and allied disorders
\end{tabular}

warty dysplasia and leptomeningeal neural tissue collections. It is believed that this classification will help the reader to orient himself in the large spectrum of NMD encountered in clinical practice.

\section{Agyria/pachygyria}

Agyria, otherwise called lissencephaly denotes a smooth brain without secondary sulci. Pachygyria, a related condition, denotes a brain with a thickened neocortex and paucity of secondary sulci. Combinations of the two occur within the same brain. In purely descriptive terms two major types of agyria have been defined as well as a number of case reports that await definite classification.

The first is an order type of migration arrest called classic lissencephaly. It is represented by an abnormal neocortex consisting of the components of the layers III, V and VI combined, separated by a cell sparse zone from radially aligned rows of non-migrated neurons, that often extend to the subependymal zone (Figure 1). The four layered sequence thus defined consists of layer 1, corresponding to the molecular layer, layer 2 harboring neurons with the morphology of the normal layers III, V and VI, layer 3 which is cell sparse and layer 4 which contains heterotopic neurons. ${ }^{43-45}$ Other features regularly seen are decreased brain size, leading to microcephaly, widened ventricles representing a fetal stage in development rather than hydrocephalus and an uncovered Sylvian fossa, representing failure of opercularization. Together with the thickened cortex these macroscopic features allow detection of agyria/pachygyria by neuroradiological means (Figure 2). Additional microscopic features are olivary heterotopia, lodged anywhere between the corpus pontobulbare and their normal station, cerebellar granule cell heterotopia and abnormally shaped dentate nuclei. Aberrant lateral corticospinal tracts in the spinal cord have been described. ${ }^{46}$ Purely pachygyric brain may lack accompanying olivary heterotopia. ${ }^{44}$ Beside various visceral and other malformations that may be associated a peculiar facial dysmorphia distinguishes a number of reported cases with classical lissencephaly. The phenotype consists of a high forehead, hollow temples, receding chin and vertical wrinkling of the forehead when crying. It has been identified as the eponym, the MillerDieker syndrome ${ }^{47}$ in recognition of the first authors. ${ }^{48.49}$ Familial occurrence was documented in the original reports. In one of the involved families ${ }^{49}$ and in another series of classical lissencephaly ${ }^{44}$ an anomaly of the short arm of chromosome 17 was suggested by unbanded karyograms. Further studies using high resolution chromosome banding revealed anomalies involving the terminal segment of chromosome $17 \mathrm{p}$ (one ring chromosome 17 and one unbalanced translocation resulting in monosomy $17 \mathrm{p} 13$ ) by Dobyns et al. ${ }^{50}$ Further karyotyping studies were performed by the same group of investigators ${ }^{51}$ on the parents of previously published familial cases, ${ }^{48.49 .52}$ including the families originally reported by Miller and by Dieker. These studies revealed balanced translocations involving chromosome 17 in one of the parents of each proband. Therefore a strong association between this syndrome and terminal $17 p$ deletion has been established. It follows that karyotype analysis and even the use of high resolution banding is indicated in each case of the Miller-Dieker syndrome if genetic advice is sought. The finding of a balanced translocation in one of the parents allows new cases to be detected antenatally by amniocentesis. Consanguinity of the parents of a case of classic 
lissencephaly revealed by autopsy was reported by Norman et al. ${ }^{53}$ High resolution banding applied to the parents' karyogram was later reported to be normal. ${ }^{51}$ The patients' facial features related in another paper ${ }^{54}$ are different from Miller-Dieker syndrome and another eponym, the Norman-Roberts syndrome, was proposed to classify the finding. According to a proposal by Dobyns et al. ${ }^{54}$ syndromes representing classical lissencephaly are to be called type I lissencephaly. Macroscopical features allowing recognition by CT-scanning have been defined ${ }^{55}$ (Figure 2).

The second major type of lissencephaly was first described by Walker in $1942 . .^{56}$ It is characterized by an almost total disorder of cortical layer formation. Instead of horizontal layers the neocortex is represented by clusters and columns of neurons perpendicular to the surface (Figure 1). This type of lissencephaly has been documented as part of an autosomal recessive disorder under the mnemonic HARD \pm E syndrome which stands for $H y d r o c e p h a l u s$ - Agyria - Retinal dysplasia with or without Encephalocoele by Pagon et al. ${ }^{57}$ The eye anomalies that form part of this syndrome affect both the anterior and posterior segments. More or less regular features include microphthalmia (often one-sided), Peter's anomaly, angle

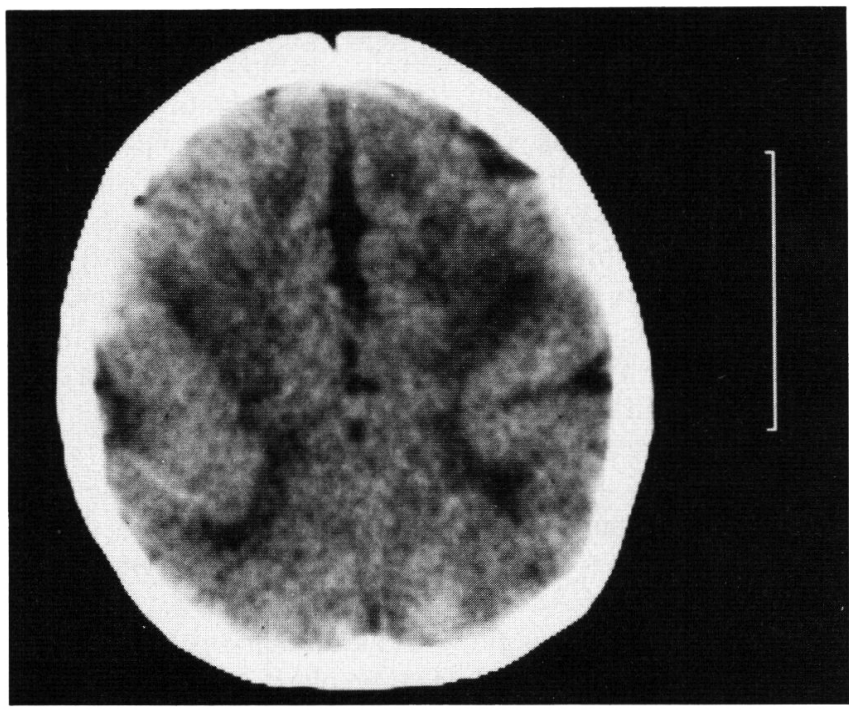

Figure 2 - Pachygyria in a 7-month male with microencephaly from consanguineous parents. Transverse high CT-section shows deep bilateral sulcus bordered by thickened cortex. Bar on right is $5 \mathrm{~cm}$. Thickness of abnormal cortex is several $\mathrm{cm}$ and should be less as $0.5 \mathrm{~cm}$.

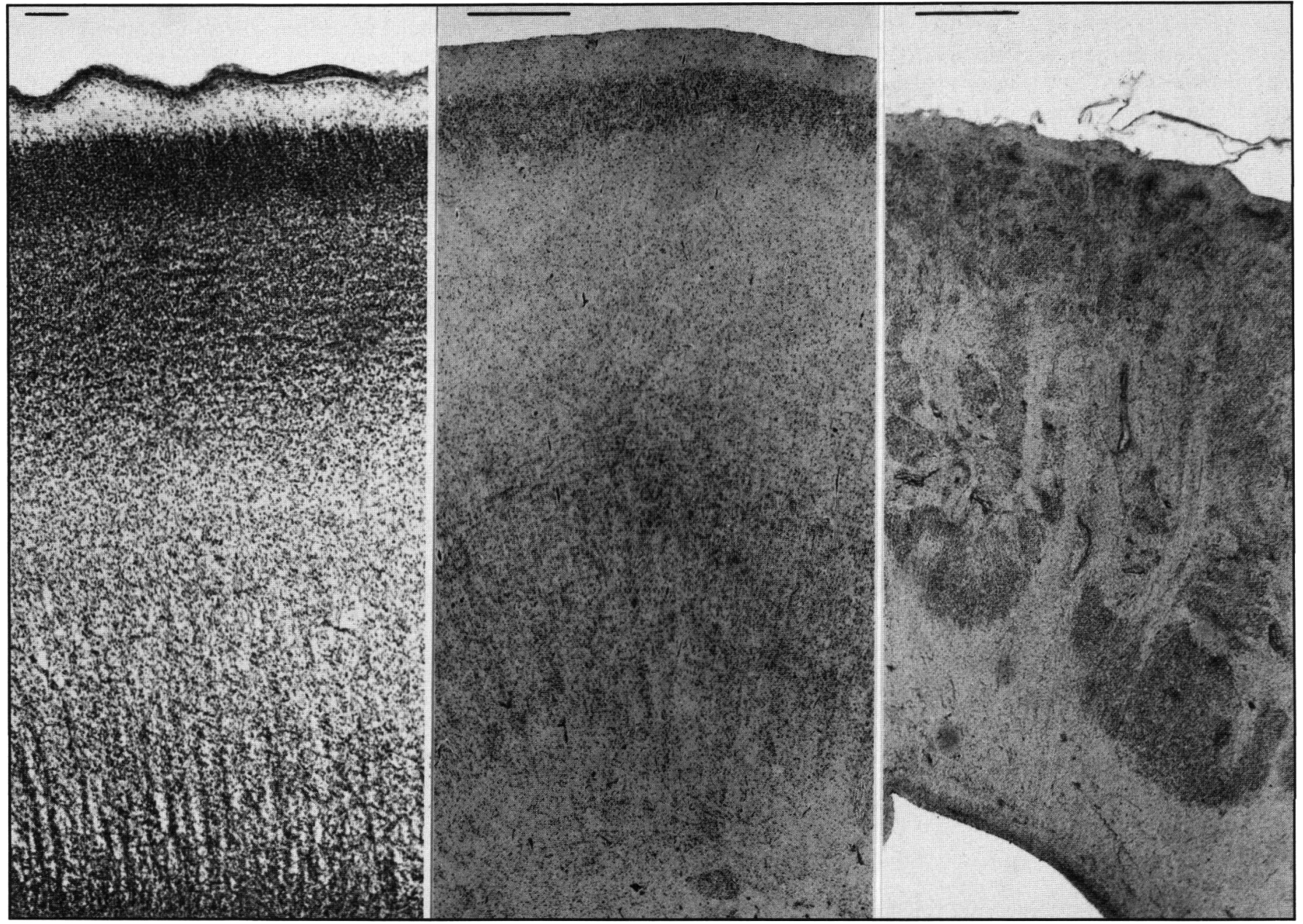

Figure I - Lefi. Cerebral hemisphere wall of a 14 week human fetus. Undifferentiated cortical plate is bordered inferiorly by migrating neurons. In the lower part of the picture migrating cells are seen arranged in vertical columns. The subventricular zone is seen in the lowest part. HE. bar 0.1 mm. Middle. Type I (classical) lissencephaly in a neonate. Neocortex is represented by a narrow ban of (pyramidal) cells, separated by a cell sparse zone from vertically arranged columns of neurons arrested during migration. Compare to previous panel. $H+E$. bar $=1 \mathrm{~mm}$. Right. Type II (Walker-Warburg) lissencephaly in a neonate. The neocortex is disorganized into ectopic clusters of neurons. $H+E$. bar $=1 \mathrm{~mm}$. 
anomalies, cataracts, persistent hyperplastic vitreous as well as retinal detachment, retinal dysplasia and optic nerve hyopolasia. ${ }^{58}$ Characteristic features of the brain include gliomesenchymal proliferation in the leptomenges encroaching on the underlying neocortex forming septa and investing the mesencephalon. The cerebral cortex - just as in clinical lissencephaly - is not the only part of the brain affected by NMD. The cerebellar folia are fused and a severe layering disorder with Purkinje-cells and granule cells lying haphazardly are seen in every case of the syndrome. In addition, the cerebellum is hypoplastic with absence of the posterior vermis and a Dandy-Walker cyst. Another feature is hypoplasia of the ventral pons with severe reduction of its nuclei and a seemingly hyperplastic corpus pontobulbare. As distinct from classical lissencephaly the inferior olivary nucleus is in its usual place without heterotopic remnants. Encephalocele or occipital dermal sinus are occasionally seen. Another characteristic feature of this disorder concerns white matter abnormalities with paucity of axons and oligodendroglia and severe hypomyelination. The corpus callosum and septum are often absent. Hydrocephalus is usually present, and probably related to the leptomeningeal abnormalities affecting CSF-flow. Since Warburg ${ }^{59,60}$ was the first to draw attention to the genetic syndrome comprising retinal dysplasia and hydrocephalus her contribution was recognized by the proposed name Warburg syndrome, ${ }^{61}$ instead of the mnemonic HARD $\pm \mathrm{E}$. Others ${ }^{62}$ suggested calling it WalkerWarburg syndrome (WWS) in regard of Walker's original contribution. A number of papers have served to delineate the clinical, genetic and pathological featues. ${ }^{58,63-66}$ The cerebral pathology of WWS is reminiscent, though not identical, to another autosomal recessive syndrome called Fukuyama's congenital cerebromuscular dystrophy (F-CMD). This syndrome is mainly though not exclusively seen in Japan. The muscular pathology is similar to congenital muscular dystrophy without cerebral involvement.$^{67}$ The pathology of the brain is characterized by microgyria with patches of agyria, the latter mainly in the temporal lobes, gliomesenchymal proliferation obliterating the subarachnoid space. Sparseness of myelinated axons, fused frontal poles and cerebellar cortical dysplasias and heterotopia are regularly seen. The disorder is inherited as an autosomal recessive trait ${ }^{68}$ and the patients may survive into adulthood, though severely handicapped. A survey of 24 Japanese autopsy cases lists 15 with partial agyria or pachygyria, 3 cases with cataract (unilateral in one patient). In one case all the features beside the muscular dystrophy were characteristic of WWS including retinal detachment and occipital dermal sinus. ${ }^{69}$ Descriptions of the neocortical dysplasia especially the agyric regions resemble WWS. ${ }^{70-72}$ This applies both to the mesenchymal obliteration of the subarachnoid spaces and the nodular arrangement of the neocortical neurons seen in WWS. ${ }^{62,64,73}$

Description of muscle pathology is sparse in WWS. Normal muscle was described in one report. ${ }^{73}$ I found changes in various muscles of a personal case of WWS consistent with congenital muscular dystrophy (unpublished). A Dutch sibship ${ }^{74}$ has been neuropathologically studied with the main findings common to both WWS and F-CMD. Beside congenital muscular dystrophy and cerebral findings characteristic of F-CMD and WWS the proband had eye anomalies. The latter anomalies not previously published consisted of persistent pupillary membrane, persistent hyaloid artery, small whitish optic nerve heads and pigment layer abnormalities. Other cases have been described that apparently compound WWS and congenital muscular dystrophy. ${ }^{75.76}$ One feature shared by WWS and F-CMD is hypo- or dysmyelination which may be of considerable help in the diagnosis of both conditions. ${ }^{55.77}$ It is not yet certain whether the two conditions represent alleles of one autosomal recessive gene. The combined occurrence of rather unique features such as the rare type of neocortical dysplasia with gliomesenchymal proliferation, cerebellar cortical dysplasia and congenital muscular dystrophy may argue in favor of a single gene involved for both conditions with WWS representing a more severe and earlier onset of the disruptive dysembryonic process. The type of lissencephaly belonging to WWS has been proposed as type II lissencephaly by Dobyns et al. ${ }^{73}$

Besides type I and type 11 lissencephaly other syndromes with lissencephaly await further studies. One is the exceedingly rare autosomal-recessive Neu-Laxova syndrome ${ }^{78}$ a lethal neonatal disease with extreme microencephaly and lissencephaly as well as grotesque skin abnormalities with ichthyosis, collodiumskin and subcutaneous edema. Extreme neopallial hypoplasia with agyria and almost vestigial cerebellum has been described in siblings. ${ }^{79}$ The neocortex was represented in the best preserved places by two layers separated by a layer without recognizable neurons. The arrangement bore similarity to type 1 lissencephaly with the upper neuronal layer probably representing the true cortex and the lowest layer probably representing heterotopic (non-migrated) neurons, but the intralaminar disarray compared to type I lissencephaly was greater. Other cases with microencephaly, lissencephaly and severe underdevelopment of derivatives from the rhombic lips have been described. 80,81 The designation "cerebro-cerebellar lissencephaly" has been proposed by Dobyns, although the homogeneity of this group remains to be established. For a comprehensive review on less established lissencephaly syndromes the reader is referred to recent papers. ${ }^{81,82}$ As a general feature it is interesting to note that the classical lissencephaly as well as cerebro-cerebellar lissencephaly are not only disorders of neuronal migration but also disorders of organ size.

\section{Microgyria, brain warts and nodular heterotopia}

Microgyri refers to small meandering gyri without intervening sulci or with intervening sulci apparently bridged by the fusion of the overlying molecular layers (Figure 3). Microgyria

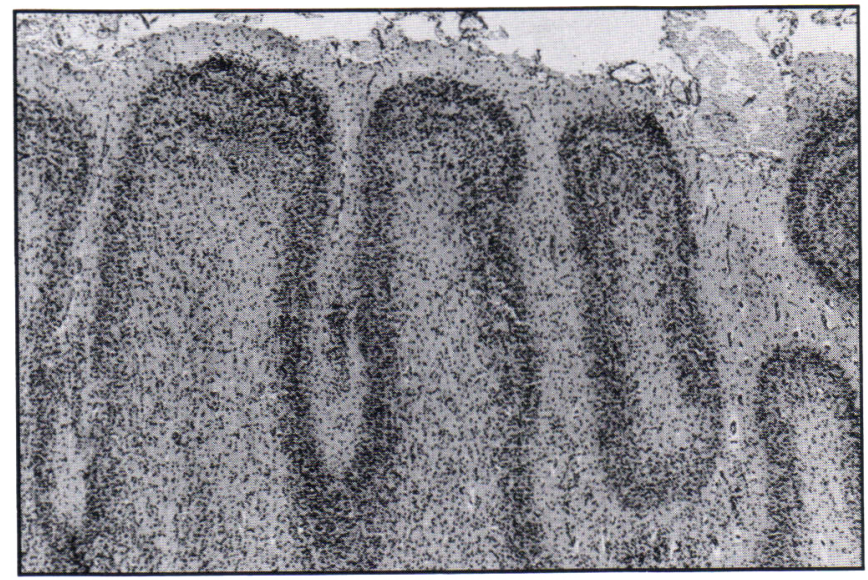

Figure 3 - Unlayered microgyria in microencephalic newborn with convulsions and general hypertonia. HE. $87 x$. 
is synonymous with polymicrogyria or micropolygyria, but should be distinguished from sclerotic microgyria or ulegyria, a pure encephaloclastic lesion resulting in atrophic small gyri and relatively broad intervening sulci. Early contributions and theories concerning origin were discussed by Bielschowsky ${ }^{83}$ The histological features of microgyria are not uniform. Layering abnormalities are the rule and mostly of two different kinds: four-layered and unlayered. The four-layered type shows the sequence: marginal layer (top) - neuronal layer - cell sparse layer with astrocytes- neuronal layer. In the unlayered type no cell-sparse zone is seen dividing upper and lower neuronal strata. A principal cause of microgyria is a circulatory disorder in utero. Frank destruction presenting as full-thickness cavities of the cerebral hemispheres (porencephalies in the classical sense of that term) are often surrounded by areas of microgyria. Microgyric regions in turn will be continuous with normal neocortical areas. ${ }^{84-86}$ Other causes of microgyria are genetic, chromosomal, infectious and toxic, to be discussed below. The mechanism that causes microgyria has not been fully settled. In one case-analysis ${ }^{87}$ it was concluded that the lower cell-sparse layer of the four-layered type represented neuronal loss and glial replacement similar to laminar cortical necrosis in the adult with hypoxic-ischemic cortical necrosis and that it represented ipso facto a post-migration accident. The theory was backed up by Golgi analysis of neuronal subtypes in the microgyric cortex which indicated that neuronal classes present in the neocortex - apart from in situ inversions - were in their proper positions.

Czech investigators ${ }^{88}, 89$ produced local microgyria in newborn rats by coagulation of the upper half of the neocortex. In this animal neuronal migration to the neocortex is still ongoing at term birth and is completed by the fourth postnatal day. Lesions made on the fourth day failed to produce microgyria. If partial necrosis, e.g. necrosis with the vascular bed preserved was induced in the upper half of the developing cortex young neurons that arrived after the lesion would migrate through the zone of partial necrosis and settle on top of this zone in a disordered way. If necrosis was of sufficient depth a microsulcus would be produced similar to human microgyria. These elegant experiments led these investigators to explain the cell-sparse zone in four-layered microgyria as the result of necrosis and the upper cellular zone as distorted migration after the accident when appropriate guidance by radial glia has been lost because these fibers did not escape necrosis.

Human fetal pathology is sparsely blessed with experiments by nature that provoke microgyria by a single accident of short duration. Two dated carbon monoxide accidents to pregnant mothers at 20 to 24 weeks $^{90}$ and 24 weeks ${ }^{91}$ gestational age caused four-layered microgyria in the surviving fetuses. (This is far beyond the time at which proliferation of neuroblasts destined for the neocortex grossly ends: 16 weeks, ${ }^{\prime}$ but it may be kept in mind that considerable numbers of young neurons generated before that time still continue to migrate afterward.) In another case ${ }^{92}$ the dating of an accident causing microgyria was provided by parabiotic twins, of which one died in utero and the other after fullterm birth. In these monochorionic twins an accident, presumably feto-fetal transfusion, caused death in one and vascular brain damage with survival in the other. The longest survivor of the two had local microgyria (overlying nodular periventricular heterotopias) in a vascular distribution. Dating of the catastrophe was provided mainly by $\mathrm{x}$-ray analy- sis of the skeleton of the fetus maceratus and was found to be 13-16 weeks. The microgyria found was unlayered. A comparable case of early parabiotic twin syndrome with bilateral lesions in vascular distribution and "cortical looping" suggestive of unlayered microgyria and heterotopic nodules was reported with a macerated co-twin whose crown-rump length of $13 \mathrm{~cm}$ would be compatible with a fetal age of 16 weeks. ${ }^{93}$ If the four dated in-utero accidents can teach us anything it appears that early fetal accidents of 13-16 weeks may cause unlayered microgyria (together with periventricular nodular heterotopias) and late fetal accidents occurring between 20 and 24 weeks cause four layered microgyria. More observations of this kind will be needed to gain more insight in the matter.

Another cause of microgyria is intrauterine infection, particularly cytomegaly ${ }^{94}$ Indirect evidence ${ }^{94,95}$ suggests that microgyria is not the result of direct viral attack but results from general perfusion failure. The extent of microgyria is quite variable from case to case. While severe cases may show signs of neurodevelopmental delay and often microcephaly, a mild microgyria restricted to limited neocortical areas may be associated with milder deficiency. A particular case recorded by Galaburda, et a ${ }^{96}$ was that of a man with developmental dyslexia, mild learning disorder and epilepsy. A number of genetic or probably genetic disorders are known to produce microgyria such as Meckel-Gruber syndrome, ${ }^{97,98}$ thanatophoric dysplasia, 99-103 Fukuyama's cerebromuscular dystrophy, ${ }^{70-72}$ BlochSulzberger syndrome. ${ }^{104}$

Microgyria also occurs in two well defined inherited disorders of metabolism related to peroxisomal dysfunction. In one of these, Zellweger's cerebro-hepato-renal syndrome, NMD results in periventricular, subcortical and intracortical heterotopia. ${ }^{105-108}$ The neocortex is often referred to as both microgyric and pachygyric, but differs from both these conditions. The microgyric aspect in Zellweger syndrome is apparently the result of fusion of distinct small gyri. The four layer pattern is not found and microgyri also line the bottom of sulci, a phenomenon referred to as "cloverleaf microgyria". ${ }^{107}$ Regions that appear macroscopically pachygyric in Zellweger syndrome are histologically almost similar to the microgyric regions. Both neurons and glial cells show light microscopic and ultrastructural changes in Zellweger syndrome and an impressive storage of lipid material of various types is seen in macrophages and astrocytes. ${ }^{109-111}$ The mechanism of NMD in Zellweger syndrome is yet unknown. Since a number of metabolic pathways are involved, all resulting from the absence or near-absence of peroxisomes ${ }^{112-115}$ no deficit can be singled out as the cause of NMD in this complex disorder. Another related autosomal recessive disorder called neonatal adrenoleukodystrophy (NALD) has deficient peroxisomes and NMD expressed as areas of microgyria ${ }^{116}$ in addition to sudanophilic leukodystrophy and adrenal atrophy. The genetic relationship to Zellweger syndrome has still to be ascertained in depth at this time. ${ }^{39}$

\section{Brainwarts (verrucose dysplasia, dysgénésie nodulaire de l'écorce)}

Brainwarts present microscopically as tiny "herniations" of the second neocortical layer into the first layer, thereby reaching the surface (Figure 4). To the naked eye the abnormality presents as a flat, round, often dimpled disk seated on the crown of a gyrus, less often in the depth of a sulcus. The phenomenon was first described in 1873 by Simon ${ }^{117}$ and called brain wart by Jakob in $1940 .{ }^{118}$ It has a predilection for the 
frontal lobes and the Rolandic areas. Mild warty dysplasia has a remarkably high incidence varying between $16 \%$ and $26 \%$ of routine autopsies if carefully looked for. ${ }^{118-120} \mathrm{~A}$ common origin with microgyria has been suggested. ${ }^{120}$ In another study ${ }^{121}$ it has been shown that not just the upper layers but all the cortical layers may participate in the formation of the "wart".

An apparently related phenomenon, often seen in autopsies of immature fetuses up to 24 weeks presents microscopically as fountains of cortical neurons apparently bursting into the first layer, that is still smooth (agyric) in accordance with fetal age. Larroche ${ }^{122}$ believes that it represents a pathological phenomenon (status verrucosus simplex) related to microgyria. Specific associations with verrucose dysplasia are rare. One that deserves mention is neonatal glutaric aciduria type II or multiple acylCoA dehydrogenase deficiency, a disorder that affects mitochondrial beta-oxidation. The association with verrucose dysplasia has been described in male sibs. ${ }^{40,41}$ The neocortical dysgenesis consisted of symmetrical reduction of the number of gyri of frontal, parietal and temporal lobes and an irregular surface with numerous warty protrusions. Microscopically these "warts" consisted of multiple small gyri that were partially fused as well as heterotopic neuronal clusters in the molecular layer and the subcortical white matter. In addition bile duct hypoplasia, cholestasis, siderosis and fatty degeneration were found in the liver of both infants as well as enlarged bilateral polycystic kidneys.

\section{Leptomeningeal heterotopias}

Heterotopic collections of astrocytes with or without admixture of ectopic neurons are often observed in conjunction with heterotopic invasions of the first neocortical layer. It appears that such heterotopia are provoked by discontinuities in the external limiting membrane that is made up by glial endfeet. Leptomeningeal heterotopia may be seen together with verrucose dysplasia (Figure 4). Large glio-neuronal heterotopia in the leptomeninges have been described in cases of familial microencephaly, pachygyria and congenital nephrotic syndrome. ${ }^{123,124}$ Leptomeningeal heterotopia are not rare. They may be seen in cases of holoprosencephaly, environmental causes of NMD (to be described below) and in vascular disruptions. ${ }^{92}$ Leptomengeal glial heterotopia may be seen

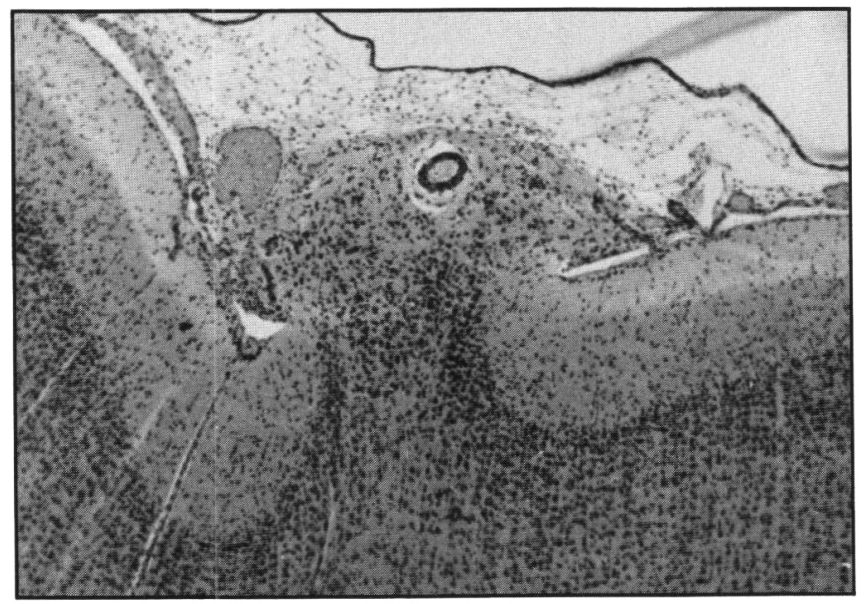

Figure 4 - Verrucous cortical dysplasia in 6 weeks old premature (35 weeks) born infant with multiple congenital anomalies, with normal karyogram. Undiagnosed syndrome. HE. $95 x$. surrounding the brainstem e.g. the mesencephalon in cases of Walker-Warburg syndrome. ${ }^{73}$ Experimentally leptomeningeal heterotopia have been provoked in neonatal rat by application of the drug 6-hydroxydopamine which causes a breach in the barrier of glial endfeet formed in the cerebellum by Bergmann glial cells as well as the basal lamina. These breaches caused the appearance of external granule cells in the subarachnoid space between the folia as well as fusion of adjacent folia. ${ }^{125}$

\section{Nodular neuronal heterotopia in the cerebral hemispheres}

Heterotopic neuronal masses represent the clearest example of NMD (Figure 5). These can occur anywhere along the migration trajectory. In the telencephalon they may occur mostly in the subependymal zone or just below the neocortex. Their degree of cytological maturation varies and may be quite impressive, to the extent that pyramidal and nonpyramidal neurons may be distinguished and both subtypes may carry abundant numbers of well developed dendritic spines in Golgi sections. ${ }^{126,127}$ The maturation achieved is likely to result in biological activity of a false kind because of improper wiring due to ectopic positioning. Large heterotopic clusters are not likely to arise after the main bulk of migrating neurons has arrived at the cortical plate, that is after the 16th week of gestation. ' The causes of nodular heterotopia are extremely varied and include genetic, chromosomal, vascular and environmental causes. These various causes are therefore described in the appropriate sections. The size of such heterotopia is usually small, often below the resolution afforded by CT- or MRIscanning apparatus. Sizable masses may occasionally be picked up by either means (Figures 6,7). Subependymal heterotopia may cause bulging of the ventricular wall, but this is not a reliable sign unless absorption characteristics (CT) or better $T_{\text {, }}$ weighted MRI images suggest grey matter.

\section{Schizencephaly and allied disorders}

Connatal clefts in the brain mantle may be accompanied by NMD. Full thickness defects that cause continuity between the arachnoid space and the lateral ventricles have been called porencephalies by Heschl (1859). ${ }^{128}$ With respect to the areas surrounding such defects these may exhibit: (1) destruction of the adjacent neocortex and white matter without NMD (2) microgyric neocortex with the histopathological structure of the four-layered type ${ }^{84-86}(3)$ neocortical and heterotopic collec-

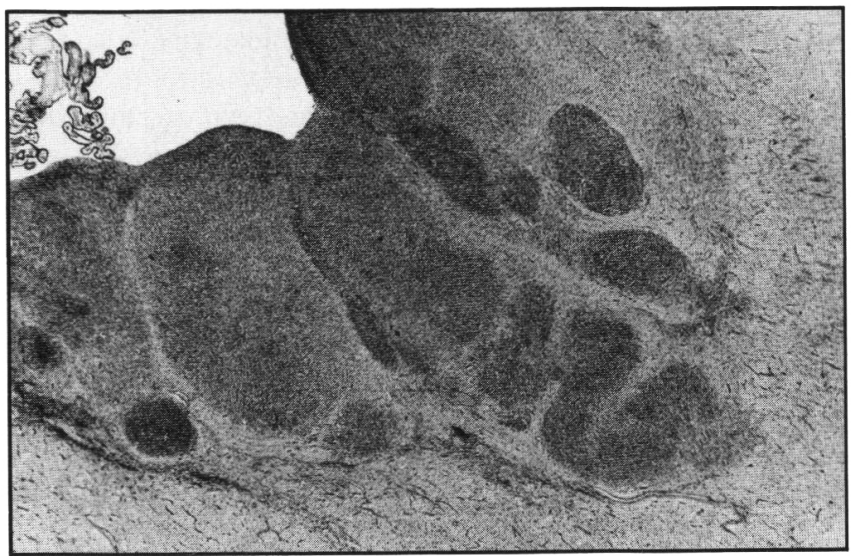

Figure 5-Periventricular heterotopic nodular masses in a newborn with occipital encephalocele. $H E .12 .7 x$. 
tions adjacent to the deeper part of the cleft up to the ventricular wall. ${ }^{129.130}$ Yakovlev $^{129}$ was the first to describe the third category under the name schizencephaly. He distinguished two types of schizencephaly. In the first type the lips of the cleft were apposed by a so-called pia-ependymal seam. ${ }^{129}$ In the second type the lips of the cleft were open. The latter type was associated with hydrocephalus. ${ }^{131}$ Clefts were covered with ectopic grey matter. Yakovlev considered schizencephaly a true malformation. As such it has become a classic subdivision amongst fetal neurodevelopmental disorders.

It remains difficult, however, to follow Yakovlev's conception of such defects as a type of focal malformation. The absence of inflammatory or gliotic lesions noted by Yakovlev does not exclude an extrinsic origin since this absence is usual in early fetal disruptions. On the other hand no familial cases or cases associated with chromosomal disorders have been reported that would support a programming failure (true malformation) as the cause of schizencephaly. It may therefore be reasonable to consider Yakovlev's schizencephaly and Heschl's porencephaly ${ }^{128}$ with full thickness defect parts of a spectrum of fetal disruptions. At one end are the post-migration period accidents resulting in lesions without associated NMD. In the middle part are the full-thickness defects with adjacent microgyria. At the other end are the cases with full-thickness defects with neocortical abnormality bordering the external part of the cleft and heterotopic grey matter masses on the inside right up to the ventricular end of the cleft. The latter type would arise before the end of the 16th week. The etiology of schizencephaly remains unsolved for the moment.

In Dekaban's series ${ }^{85}$ and in other cases reviewed ${ }^{132}$ an association with unwanted pregnancy and failed abortion is suggested. Finally the appearance of schizencephaly suggests a disruption rather than a primary malformation. Since no chromosomal or genetic basis has been established schizencephaly may be classified as low-risk with respect to genetic counselling. On the other hand fetal vascular damage might be suspected as the underlying mechanism. One type of schizencephaly (porencephaly) described by Feld and Gruner ${ }^{130}$ has absence of the septum pellucidum and blunted lateral ventricular angles due to heterotopia. These features as well as occasionally the heterotopia rimming the cleft may be discovered by CT-scanning ${ }^{133}$ (Figure 6).

\section{Cerebellar cortical dysplasias and heterotopia}

The usual type of heterotopia in the cerebellum is a sharply defined patch containing granule cells, molecular layer and Purkinje cells apparently thrown together in a more or less haphazard way. Small collections of this type or containing only granule cells as the neuronal component may be seen postmortem in normal infants, mainly in the floccular and nodular lobes. Gross lesions of this composition, macroscopically visible within the white matter or continuous with normal adjacent cerebellar cortex represent more serious malformations. In the case of continuity of the heterotopic cortex with the normal cortex the name cerebellar (poly)microgyria has been given. Because no excessive folding or small gyri are involved (as in the case of the cerebral counterpart) Friede ${ }^{134}$ has taken exception to that name and preferred the term cortical dysplasia, a practice that is followed here.

Cerebellar cortical dysplasias and mixed heterotopia are seen in a large variety of disorders described elsewhere in this article such as Zellweger syndrome and chromosomal disorders. Cortical dysplasias and heterotopia may involve small parts of the cerebellum and be of no functional significance, or may involve the whole of the cerebellum as in Walker-Warburg syndrome. They are seen relatively often in Dandy-Walker syndrome. ${ }^{135}$ Arrest of internal granule cell migration together with relative granule layer aplasia has been described in $\mathrm{GM}_{2}$-gangliosidosis. ${ }^{134}$ Subcortical nodules that contain only ganglion cells, whether related to Purkinje cells or to the roof nuclei represent another type of heterotopia. The latter has been described repeatedly in Joubert syndrome, an autosomal recessive disorder with hyperpnea/apnea, mental retardation and vermal aplasia. ${ }^{136-139}$

\section{Olivary heterotopia}

Heterotopia involving olivary components anywhere between the corpus ponto-bulbare and their normal station are a regular feature of the Miller-Dieker syndrome. ${ }^{44}$ Similar lesions have been seen occasionally in cases with Dandy-Walker syndrome without other distinguishing features, ${ }^{140}$ and on one occasion in Coffin-Siris syndrome (Table II).

\section{Disease EnTIties Associated With NMD}

\section{Associated telencephalic malformations}

Occipital encephalocoele,$^{141}$ holoprosencephaly ${ }^{142}$ and agenesis of the corpus callosum ${ }^{142.143}$ may be accompanied by

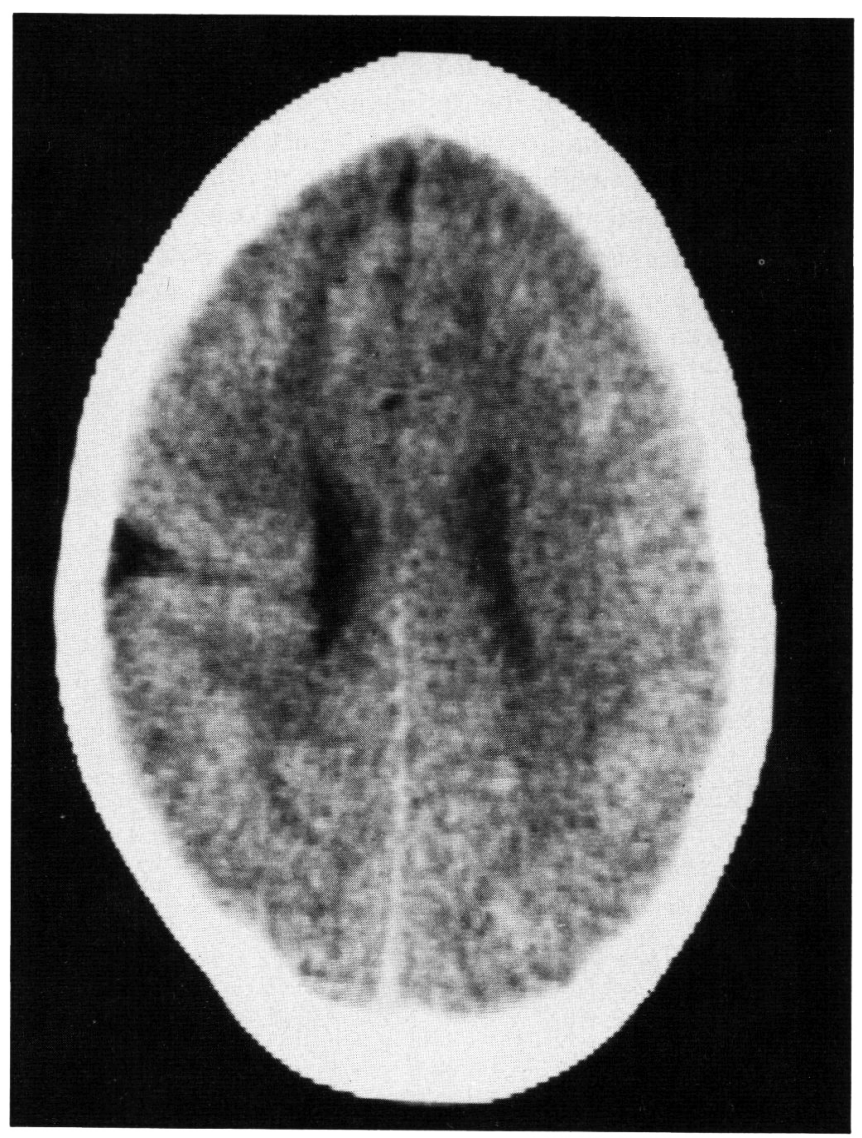

Figure 6-Schizencephaly in a 13-year old mentally defective male. Contrast enhanced CT-section shows full-thickness cerebral cleft on one side (other side similarly affected, not shown at this (evel), bordered by heterotopic grey matter. 
Table 2: Syndromes with neuronal migration disorders

\section{Classification}

Genetics

Metabolic syndromes

Zellweger s. ${ }^{105}-111$

Neonatal' adrenoleukodystrophy ${ }^{39,116}$

Glutaric aciduria $\mathrm{II}^{40.41}$

Menkes' disease ${ }^{204.205}$

$\mathrm{G}_{\mathrm{M} 2 \text { gangliosidosis }}{ }^{134}$

Neuromuscular syndromes

Walker-Warburg $\mathrm{s} . .^{56-66}$

Fukuyama syndrome ${ }^{67-77}$

Myotonic dystrophy 2017

Anterior horn arthrogryposis ${ }^{206.208}$

Neurocutaneous syndromes

Incontinentia pigmenti ${ }^{104}$

Neurofibromatosis ${ }^{166}$

Ito's hypomelanosis ${ }^{168}$

Encephalocraniocutaneous lipomatosis ${ }^{169}$

Tuberous sclerosis ${ }^{167}$

Epidermal nevus s. (Jadassohn) ${ }^{170}$

Multiple congenital anomalies-syndromes

Smith-Lemli-Opitz s. ${ }^{161}$

Oligohydramnios tetrad (Potter s.) ${ }^{162}$

Cornelia de Lange $\mathrm{s} .{ }^{163}$

Meckel-Gruber s. ${ }^{97.98}$

Oro-facio-digital s. ${ }^{147}$

Coffin-Siris s. ${ }^{210}$

ar

ar

ar

$\mathrm{xr}$

ar

ar

ar

ad

$\mathrm{xd}$

ad

?

?

Chromosomal syndromes

Trisomy $13^{151.152}$

Trisomy $18^{153-156}$

Trisomy $21^{160}$

Deletion $4 p^{157.159}$

Deletion $17 \mathrm{pl} 3$ (Miller-Dieker s.) (4.47-52 $^{4}$

Skeletal dysplasias

Thanatophoric dysplasia ${ }^{97-103}$

?

Nephrotic syndrome

Pachygyria/nephr. s. (Robain) ${ }^{123.124}$

Other CNS-dysplasias

Aicardi s. ${ }^{144}$

Joubert s. ${ }^{136-139}$

Type I lissencephaly, normal karyot. (NormanRoberts) ${ }^{53.54}$

Cerebro-cerebellar lissencephalies ${ }^{79.81}$

Hemimegalencephaly ${ }^{171-176}$

Schizencephaly and allied s. ${ }^{\text {29-131.133 }}$

Twin-syndromes

Parabiotic twin syndrome (early) ${ }^{92.93}$

Solitary reports

Ehlers-Danlos s. with heterotopia ${ }^{209}$
NMD. The first two are outside the scope of this article. Dysgenesis of the corpus callosum is found relatively often in infants with grossly disturbed mental development and epilepsy especially infantile spasms. The association between dysgenesis of the corpus callosum and NMD - both microgyria and nodular neuronal heterotopia - is so close that it is found irrespective of etiology. ${ }^{141.142}$ It is therefore very likely that similar mechanisms underlie both NMD and callosal dysgenesis. In most cases of callosal dysgenesis the origin of the corpus callosum is not absent, but represented by paired ectopic longitudinal bundles of Probst. Aberrant neurite outgrowth is therefore an essential feature of callosal dysgenesis.

The interrelation with aberrantly placed perikarya, the essence of NMD, is a tempting area for future research. Among the rare but specific causes of this association the Aicardi syndrome should be mentioned. A comprehensive recent review is available. ${ }^{144}$ In this syndrome which is exclusively present in the female sex, or at least in individuals having two X-chromosomes, chorioretinal lacunae, dysgenesis of the corpus callosum. vertebral anomalies and clinical patterns of severe developmental retardation and infantile spasms are found. Neuropathological studies reviewed mention cortical lamination disturbance as well as subcortical and subependymal heterotopia. Other supratentorial brain abnormalities reported in Aicardi syndrome are "porencephaly", hemispheric cysts and anomalies of the choroid plexus including papilloma. In at least one autopsied case $^{145}$ an interhemispheric neuroepithelial cyst was found. This suggests that some of the cysts seen on CT-scans of patients with Aicardi syndrome may be similar neuroepithelial cysts. Such cysts are believed to result from dislodged ventricular epithelium early in development. ${ }^{146}$ The association of callosal dysgenesis, NMD and neuroepithelial cysts may therefore be of more than incidental significance.

In another syndrome that is probably $\mathrm{X}$-linked dominant, the oral-facial-digital syndrome, NMD is found together with callosal dysgenesis and occasionally neuroepithelial cysts. In one report congenital coloboma in one retina and hypoplastic optic nerves were found as well, providing some interesting parallels with Aicardi syndrome. ${ }^{147}$ A relationship that may exist between NMD and intraparenchymal neuroepithelial cysts has been found in experimental animals (rats), subjected to prenatal radiation. ${ }^{148}$ The cysts originate from "neuroblast" rosettes.

\section{Chromosomal disorders}

Severe mental deficiency is expressed in most of the known chromosomal disorders. This predicts a high association with structural brain defects. Unfortunately the harvest of neuropathological observations has been small compared with the huge body of literature dealing with these disorders. Even where abnormalities have been found such as dysgenesis of the corpus callosum, such findings often did not explain the severity of neurological handicap. The elucidation of this problem had to await a more subtle technique such as the revival of the Golgi staining technique that revealed the abnormalities of the synaptic organisation of the neocortical neurons e.g. in trisomy 13 and in Down's syndrome. ${ }^{149.150}$ Gross abnormalities such as holoprosencephaly in trisomy 13 and myelomeningocoele in trisomy 18 are well known. NMD in trisomy 13 usually takes the form of heterotopic collections in the cerebellar white matter. ${ }^{151.152}$ Many cases of trisomy 18 show periventricular heterotopia in the cerebral hemispheres. ${ }^{153-156}$ Periventricular

* Limited evidence in man, but high probability in view of animal experiments; see text.

cytomegalovirus $^{94,95}$

carbonmonoxide ${ }^{90.91}$ isotretinoic acid
ethanol
181-184 methylmercury ${ }^{188.190}$

Ionizing radiation* ibid. ${ }^{201}$

Volume 14, No. I - February 1987 
heterotopia are also known in the $4 \mathrm{p}$ - syndrome, ${ }^{157}$ beside abnormalities of gyration, microgyria, increased numbers of neurons in the molecular layer of the neocortex and Purkinje cell heterotopia. ${ }^{158.159}$ Trisomy 21 (Down syndrome) is well known for a combination of developmental and regressive abnormalities. Occasonal mention has been made of nodular heterotopia in the cerebral white matter and mixed heterotopia of variable size in the cerebellar flocculus. ${ }^{160}$

\section{Multiple congenital anomalies (MCA-syndromes) and NMD}

Beside chromosomal syndromes hereditary or genetically undetermined MCA-syndromes may carry a high incidence of NMD. Some of these have already been mentioned. In the genetic group autosomal recessive disorders include the SmithLemli-Opitz syndrome with heterotopia in the cerebral and the cerebellar hemispheres, especially in those cases in which the full syndrome, including polydactyly and renal polycystic disease is expressed. ${ }^{161}$ Cerebellar heterotopia have been described in infants with Potter syndrome (oligohydramnios tetrad), ${ }^{162}$ and combined cerebral and cerebellar heterotopia in Cornelia de Lange syndrome. ${ }^{163}$ Furthermore NMD is seen in MeckelGruber syndrome (autosomal recessive), ${ }^{97.98}$ Zellweger syndrome, ${ }^{105-108}$ glutaric aciduria type II with brain warts and renal cysts. ${ }^{40,41}$ The oro-facio-digital syndrome has been mentioned already. Besides the typical features of facial skull, extremities and cerebral malformation it may also feature polycystic kidneys. ${ }^{164,165}$ The association between NMD and renal dysplasias in otherwise widely different MCA-syndromes may be significant.

\section{NMD associated with neurocutaneous syndromes}

Von Recklinghausen neurofibromatosis is associated with frank mental retardation in a small number of cases. An autopsy study of patients with this phacomatosis revealed mild abnormalities in cortical architecture, especially in those whose intelligence was subnormal. Gross malformation consisting of microgyria and nodular heterotopias was observed in a case with IQ 39. ${ }^{166}$

Tuberous sclerosis, the second neurocutaneous syndrome is particularly associated with mental retardation in a high proportion. Important abnormalities found in autopsied patients include disturbances of glial differentiation and growth of a topical nature, including subventricular nodules and giant cell tumors. Although tuberous sclerosis has a well documented prenatal onset in many cases reported, NMD does not appear a significant part of the morphological abnormalities encountered. One report describes malpositioning of pyramidal neurons in a cortical tuber studied with the Golgi technique. ${ }^{167}$ Of the rarer neurocutaneous syndromes grey matter heterotopia together with glial proliferation has been observed in Ito's hypomelanosis. ${ }^{168}$ Microgyria has been reported in encephalocraniocutaneous lipomatosis ${ }^{169}$ and leptomeningeal glioneural and white matter heterotopias, together with microgyria and gliomatosis in a newborn with severe epidermal nevus syndrome. ${ }^{170}$ Microgyria in Bloch-Sulzberger syndrome has already been mentioned. ${ }^{104}$

\section{NMD associated with hemimegalencephaly}

A number of pathological case reports exist on infants and young children with hemimegalencephaly, ${ }^{171-176}$ a condition with one hyperplastic cerebral hemisphere with gyral abnormali- ties (pachygyria), giant pyramidal neurons (restricted to the pathological side), beside subcortical ${ }^{171-173}$ and glioneural leptomeningeal heterotopia. ${ }^{174} \mathrm{Cy}$ tomorphometric studies in some of these cases ${ }^{172,173,176}$ proved increased nuclear volume ${ }^{172,173}$ and an apparently increased DNA content ${ }^{172.173}$ in the affected neurons, which led to a suggestion of topical heteroploidy. The presence of giant neurons in the brainstem ipsilateral to the giant hemisphere in some cases ${ }^{173.174}$ and the presence of ipsilateral corporeal hypertrophy in some cases (reference list of Bignami, et al 1968) 172 would imply that the dysembryonic influence causing this growth disturbance is rather limited to one side of the main embryonic axis, and therefore may well originate during the earliest mitotic divisions of the embryo.

The presence of glial nodules and giant glial cells in the absence of gross degenerative changes in some of the reported cases ${ }^{172,174,175}$ is reminiscent of disorders affecting growth and proliferation in a topical nature, in other words the phacomatoses. The latter opinion concurs with the pathological findings in an autopsy case of the one neurocutaneous syndrome that causes hemimegalencephaly: the organoid nevus syndrome or epidermal nevus syndrome. ${ }^{170}$ The hemimegalencephaly cases are also remarkable for they present rare examples of brain malformations with NMD in which brain volume is increased rather than decreased. An MRI-example of hemimegalencephaly is shown in Figure 7.

NMD associated with megalencephaly and elevated insulin-like growth factor II

A single case report on congenital megalencephaly with grossly disturbed neocortical development and NMD with elevated levels of the growth hormone dependent insulin like growth factor II (IGF II) in CSF (at autopsy) and in postmortem brain samples appeared recently. ${ }^{42}$ This interesting study offers a new approach to cases of "intrinsic" disturbances of bulk growth whether associated with NMD or not.

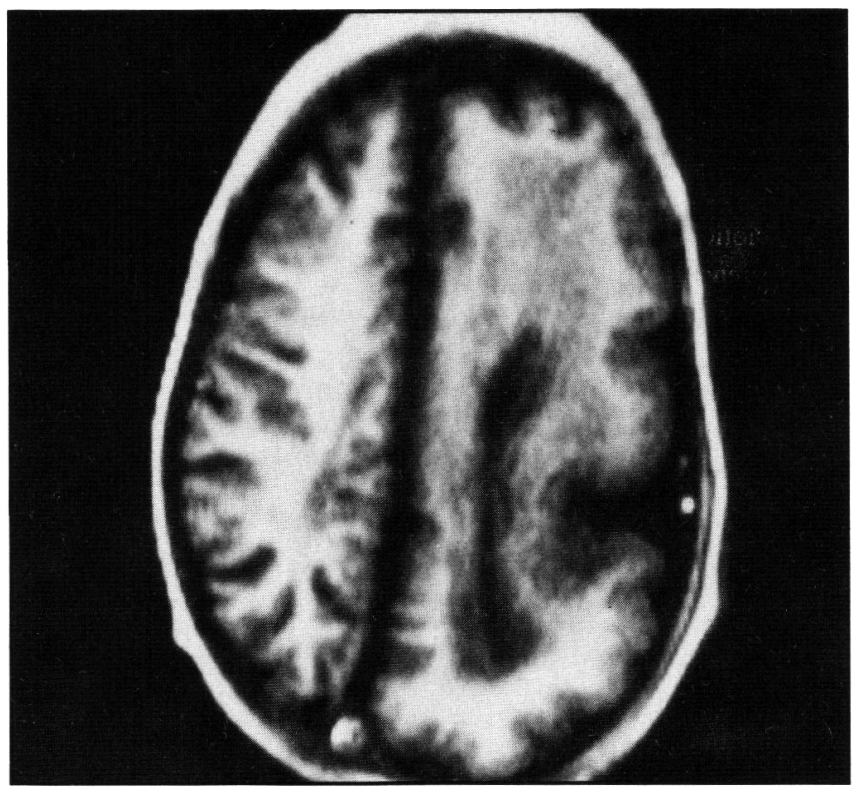

Figure 7 - Hemimegalencephaly in a 2 year old female demonstrated in transverse inversion recovery sequence MRI-section. The abnormal hemisphere seen on the right shows paucity of secondary sulci, deep parietal sulcus and masses of poorly delineated grey matter within the central white matter. 


\section{Environmental Causes of NMD}

Confirmed hazards to neuronal migration in the human fetus are isotretinoic acid, ethanol, methylmercury, radiation and radiomimetics. The effects of fetal hypoxia have already been mentioned.

\section{Isotretinoic acid}

Isotretinoic acid, an alcohol-soluble synthetic analogue of vitamin A prescribed as an oral medication for severe cystic acne has become associated with craniofacial, cardiac, thymic and central nervous system malformations in fetuses exposed during the first trimester. A spectrum of cerebral abnormalities have been described which includes hydrocephalus, microcephaly, holoprosencephaly (one case), vermalaplasia, cerebellar cortical dysplasia, dystopic corticospinal tracts in the brainstem, malformed inferior olivary nucleus, malformed allocortex, focal neocortical agyria. A consistent abnormality appears leptomeningeal neuroglial heterotopia that may affect both supra- and infratentorial structures. ${ }^{177-179}$

\section{Ethanol}

In utero exposure to ethanol produces the fetal alcohol syndrome (FAS), a dysmorphic syndrome with intrauterine as well as postnatal growth retardation, a characteristic facial dysmorphia with prominent midfacial hypoplasia, microcephaly, mental retardation and often cardiac defects. ${ }^{180.181}$ Increased rate of stillbirth is another recognized hazard. Morphological brain abnormalities are variable and logically depend on time and degree of exposure and possibly on additional adverse conditions such as dietary deficiencies and other addictions including heavy smoking. A spectrum of neuropathological findings has been reported ${ }^{181-184}$ in infants and fetuses, which includes microencephaly, hydrocephalus, arhinencephaly, callosal dysgenesis microdysplasias of cerebral and cerebellar cortices, dentate- and olivary nuclei, hydromyelia, porencephaly and spongy degeneration in diencephalic structures and optic nerves. NMD is mainly seen as leptomeningeal neuroglial heterotopia of various extent overlying both supra- and infratentorial parts of the neuraxis. Such neuroglial heterotopia appear to arise through thin bridges of neural tissue that connect the heterotopia with the underlying neuraxial structures. Neuronal hetrotopia within the cerebral hemispheres are occasionally found. The neuropathological series quoted undsubtedly are the most serious part of the spectrum of sequelae. Moderate mental retardation and microcephaly with behavioral disorders, characteristically present in long-term survivors may have other structural correlates than NMD. A large number of animal experiments involving different species and different protocols of exposure all point to the potentially damaging effects of ethanol on the shaping process in various parts of the brain. ${ }^{185-187}$

\section{Methylmercury}

In the 1950's methylmercury was the cause of large scale industrial pollution around Minamata Bay (Japan) carried by consumption of poisoned fish from the bay. So-called Minamata disease caused severe neurological deficits. Also babies who were exposed in utero were affected by fetal Minamata disease. ${ }^{188}$ Severe neuronal losses in the cerebral and cerebellar cortices were described, but also signs of NMD ${ }^{188}$ Another epidemic of methylmercury intoxication in Iraq (1970-1971) was caused by consumption of homemade bread prepared from seed grain of wheat treated with methylmercury fungicide. Prenatally exposed babies suffered from psychomotor retardation even when the clinical symptoms in their mothers had been mild or absent. ${ }^{189}$ The brains of two infants expiring soon after birth have been described in detail by Choi et al. ${ }^{190}$ They had been exposed between 6 and 8 and between 8 and 10 weeks fetal age. Mercury intoxication was confirmed by its determination in the blood and was found to be higher in the infants at delivery as in their mothers, confirming delayed fetal clearance. The babies were small for gestational age. Major findings consisted of neuronal heterotopia in the cerebral hemispheres and in the cerebellum, and leptomeningeal heterotopia. In the cerebral cortex, layering abnormalities and undulating upper cortical layers resembling microgyria were apparent. Large numbers of gemistocytic astrocytes containing mercury were shown histochemically. A relatively large number of reports relate to the influence of methylmercury on experimental animal fetuses (for review see Choi 1983). ${ }^{191}$ The influence of methylmercury on migrating neurons has been studied in vitro by exposing human fetal explants containing migrating neurons to methylmercury. Methylmecury chloride caused abrupt cessation of active movement of cells in these cultures. The initial site of damage appeared to be the neuritic membrane in the vicinity of growth cones. ${ }^{192}$

Electron microscopy suggested that the initial event was the disappearance of neurotubules necessary for structural support and for axoplasmic transport. Similar damage was observed in cultures of astroglial cells. Decreased DNA-synthesis probably resulted from interference with mitotic spindles. ${ }^{193}$ The outcome of these studies may have a bearing not only on public health policies surrounding organic mercury, but also on other agents and intrinsic processes that affect cytoskeletal proteins and in this way affect neuronal migration.

\section{Ionizing radiation and cytostatic drugs}

Pregnant rats subjected to roentgen irradiation between the 14th and 16th day produce offspring with neuronal heterotopia in the cerebral hemispheres. If radiation is applied between the 19 th and 21 st day disordered cerebellar migration is found. ${ }^{148,194}$ Other deficiencies observed were microencephaly, absent corpus callosum, hydrocephalus and rosette formations. Cerebellar granule cell ectopia were seen in rats after birth if radiation took place before migration from the external granule cell layer ended. ${ }^{195}$ Similar observations could be made with respect to the cerebral hemispheres in mice when irradiated between the 10 th and 14th day of gestation. ${ }^{196}$

The experience in man has been summarized by the description of the sequelae in survivors of prenatal exposure to the atomic bomb of Hiroshima ${ }^{197}$ and by the timetable of the effects of prenatal radiation injury obtained from a number of casereports on therapeutic pelvic irradiation during pregnancy. ${ }^{198}$ In the case of the Hiroshima bomb microcephaly (below - 2 S.D.) was the most obvious sequel and this was especially prevalent in cases that had been exposed between the 7th and 15 th week gestational age. Most though not all of the cases had learning disorders. ${ }^{197}$ Later analyses have confirmed this. ${ }^{199,200}$ Fetal exposure to pelvic radiation, mainly due to the vogue of radiation for all kinds of purposes in the twenties and thirties has provided another source. ${ }^{198} \mathrm{~A}$ timetable constructed from these individual reports showed that radiation incurred between 3 to 4 and 11 weeks caused microcephaly, mental retardation 
and stunted growth, besides eye, skeletal, and genital abnormalities. Between 11 and 16 weeks radiation resulted in microcephaly, mental retardation and stunted growth without associated injury. Similar effects though milder were encountered in cases of radiation between 16 and 20 weeks. Cerebellar NMD has been described in a case where intrapelvic radium had been applied ending "near the seventh month". ${ }^{201}$ Through the sparsity of detailed neuropathological studies the results of experimental studies cited above find no confirmation or exclusion in man. Since the effects that can be observed in man during life such as eye abnormalities, stunted growth and microcephaly are closely similar to those that are encountered in animal experiments the likelihood of NMD being eventually found in surviving human cases through the use of magnetic resonance imaging or postmortem investigation is high. Animal experiments with cystostatic drugs e.g. cytosine arabinoside indicate similar results as those obtained with ionizing radiation. ${ }^{202.203}$

\section{ACKNOWLEDGMENTS}

I thank Prof. Dr. F.C. Stam, Head of Dept. of Neuropathology, Free University Hospital, Amsterdam for his continuous support and constructive criticism. Dr. J. Aicardi, Dr. Ph. Evrard, Dr. B.H. Choi, Dr. H.B. Uylings provided fruitful discussions.

\section{REFERENCES}

1. Sidman RL, Rakić P. Neuronal migration, with special reference to developing human brain: a review. Brain Res 1973; 62: 1-35.

2. Levitt P, Cooper ML, Rakić P. Coexistence of neuronal and glial precursor cells in the cerebral ventricular zone of the fetal monkey: an ultrastructural immunoperoxidase analysis. J Neurosci 1981; 1: 27-39.

3. Angevine JB Jr, Sidman RL. Autoradiographic study of cell migration during histogenesis of cerebral cortex of the mouse. Nature 1961; 192: 766-768.

4. Berry M, Rogers AW. The migration of neuroblasts in the developing cerebral cortex. J Anat 1965; 99: 691-709.

5. Marin Padilla M. Dual origin of the mammalian neocortex and evolution of the cortical plate. Anat Embryol 1978; 152: 109-126.

6. Ramón y Cajal S. Histologie du Système Nerveux de l'Homme et des Vertébrés. Paris: Maloine. 1911; Vol 2: 847-861.

7. Rakić $\mathbf{P}$. Mode of cell migration to the superficial layers of fetal monkey neocortex. J Comp Neurol 1972; 145: 61-84.

8. Levitt $P$, Rakić P. Immunoperoxidase localization of glial fibrilary acidic protein in radial glial cells and astrocytes of the developing rhesus monkey brain. J Comp Neurol 1980; 193: 417-448.

9. Antanitus DS, Choi BH, Lapham LW. The demonstration of glial fibrillary acidic protein in the cerebrum of the human fetus by indirect immunofluorescence. Brain Res 1976; 103: 613-616.

10. Choi BH, Lapham LW. Radial glia in the human fetal cerebrum: a combined Golgi, immunofluorescent and electron microscopic study. Brain Res 1978; 148: 295-311.

11. Caviness VS Jr, Sidman RL. Time of origin of corresponding cell classes in the cerebral cortex of normal and reeler mutant mice: an autoradiographic study. J Comp Neurol 1973; 148; 141-153.

12. Caviness VS Jr. Patterns of cell and fiber distribution in the neocortex of the reeler mutant mouse. J Comp Neurol 1976; 170 : 435-448.

13. Caviness VS Jr, Pinto-Lord MC, Evrard P. The development of laminated patterns in the mammalian neocortex. In: TG Connelly et al eds. Morphogenesis and pattern formation. New York: Raven Press 1981; 103-126.

14. Caviness VS Jr, Frost DO. Thalamocortical projections in the reeler mutant mouse. J Comp Neurol 1983; 219: 182-202.

15. Terashima $\mathrm{T}$, Inoue $\mathrm{K}$, Inoue $\mathrm{Y}$, et al. Distribution and morphology of corticospinal tract neurons in reeler mouse cortex by the retrograde HRP method. J Comp Neurol 1983; 218: 314-326.
16. Schmechel DE, Rakić P. A Golgi study of radial glial cells in developing monkey telencephalic morphogenesis and transformation into astrocytes. Anat Embryol 1979; 156: 115-152.

17. Choi BH, Kim RC, Lapham LW. Do radial glia give rise to both astroglial and oligodendroglial cells? Dev Brain Res 1983; 8: 119-130.

18. Choi BH, Kim RC. Expression of glial fibrillary acidic protein in immature oligodendroglia. Science 1984; 223: 407-409.

19. Choi BG, Kim RC. Expression of glial fibrillary acidic protein by immature oligodendroglia and its implications. J Neuroimmunology 1985; 8: 215-235.

20. Ranke $O$. Beiträge zur Kenntnis der normalen und pathologischen Hirnrindenbildung. Beitr Anat allg Pathol 1910; 47: 51-125.

21. Miale IL, Sidman RL. An autoradiographic analysis of histogenesis in the mouse cerebellum. Exp Neurol 1961; 4: 277-296.

22. Rakić $P$. Neuron-glia relationship during granule cell migration in developing cerebellar cortex. A Golgi and electronmicroscopic study in Macacus rhesus. J Comp Neurol 1971; 141: 283-312.

23. Choi BH, Lapham LW. Evolution of Bergmann glia in developing human fetal cerebellum: A Golgi, electronmiscroscopic and immunofluorescent study. Brain Res 1980; 190: 369-383.

24. Essick CR. The corpus ponto-bulbare, a hitherto undescribed nuclear mass in the human hindbrain. Am J Anat 1907; 7: 119-135.

25. Essick CR. The development of the nuclei pontis and the nucleus arcuatus in man. Am J Anat 1912; 13: 25-54.

26. Taber Pierce E. Histogenesis of the nuclei griseum pontis, corporis pontobulbaris and reticularis tegmenti pontis (Bechterew) in the mouse. J Comp Neurol 1966; 126: 219-240.

27. Ellenberger CJ, Hanaway J, Netsky MG. Embryogenesis of the inferior olivary nucleus in the rat: a radioautographic study and a re-evaluation of the rhombic lip. J Comp Neurol 1969; 137: $71-88$.

28. Rakić P. Sidman RL. Weaver mutant mouse cerebellum: defective neuronal migration secondary to abnormality of Bergmann glia. Proc Nat Acad Sci USA 1973; 70: 240-244.

29. Goldowitz D, Muller RJ. Granule cell as a site of gene action in the weaver mouse cerebellum: evidence from heterozygous mutant chimeras. J Neurosci 1982; 2: 1474-1485.

30. Hatten ME, Liem RKH, Mason CA. Defects in specific associations between astroglia and neurons occur in microcultures of weaver mouse cerebellar cells. J Neurosci 1984; 4: 1163-1172.

31. Hatten ME, Mason CA. Neuron-astroglia interaction in vitro and in vivo. TINS 1986; 168-172.

32. Edelman GM. Modulation of cell adhesion during induction, histogenesis, and perinatal development of the nervous system. Ann Rev Neurosci 1984; 7: 339-377.

33. Porter R, Whelan J, eds. Basement membranes and cell movement. Ciba Foundation Symposium 108. London: Pitman 1984.

34. Goodman CS, Bastiani MJ, Doe CQ, et al. Cell recognition during neuronal development. Science 1984; 225: 1271-1279.

35. Kotrla KJ, Goodman CS. Transient expression of a surface antigen on a small subset of neurons during embryonic development. Nature 1984; 311: 151-153.

36. Taghart PH, Doe CQ, Goodman CS. Cell determination and regulation during development of neuroblasts and neurones in grasshopper embryo. Nature 1984; 307: 163-165.

37. Pegg AE, McCann PP. Polyamine metabolism and function. Am J Physiol 1982; 243: c212-221.

38. Bartolomé JV, Schweitzer L, Slotkin TA, et al. Impaired development of cerebellar cortex in rats treated postnatally with -difluoromethylornithine. Int J Dev Neuroscience (in press).

39. Kelley RI, Datta NS, Dobyns WB, et al. Neonatal adrenoleukodystrophy: new cases, biochemical studies, and differentiation from Zellweger and related peroxisomal polydystrophy syndromes. Am J Med Genet 1986; 23: 869-901.

40. Lehnert W, Wendel U, Lindenmaier S, et al. Multiple acyl-CoA dehydrogenation deficiency (glutaric aciduria type II), congenital polycystic kidneys, and symmetric warty dysplasia of the cerebral cortex in two brothers. I. Clinical, metabolical and biochemical findings. Eur J Pediatr 1982: 139: 56-59.

41. Böhm N, Uy J, Kiessling M, et al. Multiple acyl-CoA dehydrogenation deficiency (glutaric aciduria type II), congenital polycystic kidneys, and symmetric warty dysplasia of the cerebral cortex in two newborn brothers. II. Morphology and pathogenesis. Eur J Pediatr 1982; 139: 60-65. 
42. Schoenle EJ, Haselbacher GK, Briner J, et al. Elevated concentration of IGF II in brain tissue from an infant with macrencephaly. J Pediatr 1986; 108: 737-740.

43. Stewart RM, Richman DP, Caviness VS Jr. Lissencephaly and pachygyria. An architectonic and topographical analysis. Acta Neuropathol 1975; 31: 1-12.

44. Jellinger K, Rett A. Agyria - pachygyria (lissencephaly syndrome). Neuropädiatrie 1976; 7: 66-90.

45. Caviness VS Jr, Williams RS. Cellular pathology of developing human cortex. In: Katzman R, ed. Congenital and acquired cognitive disorders. New York: Raven Press 1979; 69-89.

46. Roessman U, Hori A. Agyria (lissencephaly) with anomalous pyramidal crossing. Case report and review of the literature. J Neurol Sci 1985; 69: 357-364.

47. Jones KL, Gilbert F, Kaveggia EG, et al. The Miller-Dieker syndrome. Pediatrics 1980; 66: 277-281.

48. Miller JQ. Lissencephaly in 2 siblings. Neurology 1963; 13:841-850.

49. Dieker H, Edwards RH, $\mathrm{Zu}$ Rhein, et al. The lissencephaly syndrome. Birth defects: Original article series 1969;5(2): 53-64.

50. Dobyns WB, Stratton RF, Parke J, et al. Miller-Dieker syndrome: lissencephaly and monosomy $17 \mathrm{p}$. J Pediatr 1983; 102: 552-558.

51. Stratton RF, Dobyns WB, Airhart SD, et al. New chromosomal syndrome: Miller-Dieker syndrome and monosomy $17 \mathrm{pl}$. Hum Genet 1984; 67: 193-200.

52. Garcia CA, Dunn D, Trevor R. The lissencephaly (agyria) syndrome in siblings. Computerized tomographic and neuropathologic findings. Arch Neurol 1978; 35: 608-611.

53. Norman MG, Roberts M, Sirois J, et al. Lissencephaly. Can J Neurol Sci 1976; 3: 39-46.

54. Dobyns WB, Stratton FR, Greenberg F. Syndromes with lissencephaly. 1: Miller-Dieker and Norman-Roberts syndromes and isolated lissencephaly. Am J Med Genet 1984; 18: 509-526.

55. Dobyns WB, McCluggage CW. Computed tomographic appearance of lissencephaly syndromes. Am J Neurorad 1985; 6: 545-550.

56. Walker AE. Lissencephaly. Arch Neurol Psychiat 1942; 48: 12-29.

57. Pagon RA, Chandler JW, Collie WR, et al. Hydrocephalus, agyria, retinal dysplasia, encephalocoele (HARD \pm E syndrome): An autosomal recessive condition. Birth defects: Original article series 1978; 14(6B): 233-241.

58. Pagon RA, Clarren SK, Milam DT Jr, et al. Autosomal recessive eye and brain anomalies: Warburg syndrome. J Pediatr 1983; 102: $542-546$.

59. Warburg $\mathbf{M}$. The heterogeneity of microphthalmia in the mentally retarded. Birth defects; Original article series 1971;7(3): 136-154.

60. Warburg M. Heterogeneity of congenital retinal non-attachment, falciform fold and retinal dysplasia. Hum Hered 1976;26: 137-148.

61. Pagon RA, Clarren SK. HARD \pm E: Warburg's syndrome. Arch Neurol 1981; 38: 66 .

62. Williams RS, Swisher Cn, Jennings $M$, et al. Cerebro-ocular dysgenesis (Walker-Warburg syndrome): Neuropathologic and etiologic analysis. Neurology 1984; 34: 153!-1541.

63. Chemke J, Czernobilsky B, Mundel G, et al. A familial syndrome of central nervous system and ocular malformations. Clin Genet 1975; $7: 1-7$.

64. Chan CC, Egbert PR, Herrick MK, et al. Oculocerebral malformations. A reappraisal of Walker's "Lissencephaly". Arch Neurol 1980; 37: 104-108.

65. Whitley CB, Thompson ThR, Mastri AR, et al. Warburg syndrome: lethal neurodysplasia with autosomal recessive inheritance. J Pediatr 1983; 102: 547-551.

66. Bordarier C, Aicardi J, Goutières F. Congenital hydrocephalus and eye abnormalities with severe developmental brain defects: Warburg's syndrome. Ann Neurol 1984; 16: 60-65.

67. Nonaka I, Chou SM. Congenital muscular dystrophy. Vinken PJ, Bruyn GW eds. Handbook of Clinical Neurology vol. 41. Diseases of Muscle Part II. Amsterdam: North Holland Publ Co $1979 ; 27-50$.

68. Fukuyama Y, Ohsawa M. A genetic study of the Fukuyama type of congenital muscular dystrophy. Brain Develop (Tokyo) 1984; 6: 373-390.

69. Fukuyama $Y$, Ohsawa M, Suzuki H. Congenital progressive muscular dystrophy of the Fukuyama type-Clinical, Genetic and Pathological considerations. Brain Develop (Tokyo) 1981; 3: $1-29$.
70. Kamoshita S, Konishi Y, Segawa M, et al. Congenital muscular dystrophy as a disease of the central nervous system. Arch Neurol 1976; 33: 513-516.

71. Murakami T, Konishi Y, Takamiya M, et al. Congenital muscular dystrophy associated with micropolygyria - report of two cases. Acta Pathol Jap 1975; 25: 599-612.

72. Takada K, Nakamura $\mathrm{H}$, Tanaka J. Cortical dysplasia in congenital muscular dystrophy with central nervous system involvement (Fukuyama type). J Neuropathol Exp Neurol 1984; 43: 395-407.

73. Dobyns WB, Kirkpatrick JB, Hittner HM, et al. Syndromes with lissencephaly. II: Walker-Warburg and cerebro-oculo-muscular syndromes and a new syndrome with type II lissencephaly. Am J Med Genet 1985; 22: 157-195.

74. Krijgsman JB, Barth PG, Stam FC, et al. Congenital muscular dystrophy and cerebral dysgenesis in a Dutch family. Neuropädiatrie 1980; 11: 108-120.

75. Dambska M, Wisniewski K, Sher J, et al. Cerebro-oculo-muscular syndrome: a variant of Fukuyama congenital cerebromuscular dystrophy. Clin Neuropathol 1982; 1: 93-98.

76. Towfighi J, Sassani JW, Suzuki K, et al. Cerebro-ocular dysplasia - muscular dystrophy (COD-MD) syndrome. Acta Neuropathol 1984; 65: 110-123.

77. Yoshioka M, Okuno T, Ito M, et al. Congenital muscular dystrophy (Fukuyama type). Repeated CT studies in 19 children. Comp Tomogr 1981; 5: 81-88.

78. Lazjuk GI, Lurie IW, Ostrowskaja TI, et al. The Neu-Laxova syndrome - A distinct entity. Am J Med Genet 1979; 3: 261-267.

79. Barth PG, Mullaart R, Stam FC, et al. Familial lissencephaly with extreme neopallial hypoplasia. Brain Develop (Tokyo) 1982; 4: $145-151$.

80. Sarnat HB, Rybak G, Kotagal S, et al. Cerebral embryopathy in late first trimester: possible association with swine influenza vaccine. Teratology 1979; 20: 93-100.

81. Dobyns WB. Further comments on the lissencephaly syndromes (letter). Am J Med Genet 1985; 22: 197-211.

82. Dobyns WB. Developmental aspects of lissencephaly and the lissencephaly syndromes. Birth defects (in press).

83. Bielschowsky M. Ueber Mikrogyrie. J Psychol Neurol (Lpz) $1915 ; 22: 1-47$.

84. Norman RM, Urich H, Woods GE. The relationship between prenatal porencephaly and the encephalomacias of early life. J Ment Sci 1958; 104: 758-771.

85. Dekaban A. Large defects in cerebral hemispheres associated with cortical dysgenesis. J Neuropathol Exp Neurol 1965; 24: 512-530.

86. Levine DN, Fisher ma, Caviness VS Jr. Porencephaly with microgyria: A pathologic study. Acta Neuropathol 1974; 29: 99-113.

87. Williams RS, Caviness VS Jr. The cellular pathology of microgyria. A Golgi analysis. Acta Neuropathol 1976: 36: 269-283.

88. Dvořák K, Feit J. Migration of neuroblasts through partial necrosis of the cerebral cortex in newborn rats. Contribution to the problems of morphological development and developmental period of cerebral microgyria. Acta Neuropathol (Berl) 1977:38: 203-212.

89. Dvořák K, Feit J, Juránková Z. Experimentally induced focal microgyria and status verrucosis deformis in rats - pathogenesis and interrelation, histological and autoradiographical study. Acta Neuropathol 1978; 44: 121-129.

90. Hallervorden J. Ueber eine Kohlenoxydvergiftung im Fetalleben mit Entwicklungsstörung der Hirnrinde. Allg Z Psychiatr 1949 124: 289-298.

91. Bankl J, Jellinger K. Zentralnervöse Schäden nach fetaler Kohlenoxidvergiftung. Beitr path Anat 1967: 135: 350-376.

92. Barth PG, van der Harten JJ. Parabiotic twin syndrome with topical isocortical disruption and gastroschisis. Acta Neuropathol 1985; 67: 345-349.

93. Norman MG. Bilateral encephaloclastic lesions in a 26 week gestation fetus: effect on neuroblast migration. Can J Neurol Sci 1980; 7: 191-194.

94. Friede RL, Mikolasek J. Postencephalitic porencephaly, hydranencephaly or polymicrogyria. A Review. Acta Neuropathol 1978; 43: 161-168. 
95. Marques Dias MJ, Harmant-van Rijckevorsel G, Landrieu, et al. Prenatal cytomegalovirus disease and cerebral microgyria: evidence for perfusion failure, not disturbance of histogenesis, as the major cause of fetal cytomegalovirus encephalopathy. Neuropediatrics $1984 ; 15: 18-24$.

96. Galaburda AM, Kemper ThL. Cytoarchitectonic abnormalities in developmental dyslexia: a case study. Ann Neurol 1979;6: 94-100.

97. Hori A, Orthner $\mathrm{H}$, Kohlschütter $\mathrm{A}$, et al. CNS dysplasia in dysencephalia splanchnocystica (Gruber's syndrome). Acta Neuropathol 1980; 51: 93-97.

98. Paetou A, Salonen R, Haltia M. Brain pathology in the Meckel syndrome: a study of 59 cases. Clin Neuropathol 1985; 4: 56-62.

99. Goutières F, Aicardi J, Farkas-Bargeton E. Une malformation cérébrale particulière associée au nanisme thanatophore. Rev Neurol 1971; 125: 435-440.

100. Wongmongkolrit Th, Bush M, Roessmann U. Neuropathological findings in thanatophoric dysplasia. Arch Pathol Lab Med 1983; 107: 132-135.

101. Hori A, Friede RL, Fischer G. Ventricular diverticles with localized dysgenesis of the temporal lobe in cloverleaf skull anomaly. Acta Neuropathol 1983; 60: 132-136.

102. Ho K-L, Chang C-H, Yang SS, et al. Neuropathologic findings in thanatophoric dysplasi. Acta Neuropathol 1984; 63: 218-228.

103. Shigematsu H, Takashima S, Otani K, et al. Neuropathological and Golgi study on a case of thanatophoric dysplasia. Brain Develop (Tokyo) 1985; 17: 628-632.

104. O'Doherty N. Bloch-Sulzberger syndrome. Incontinentia pigmenti. In: Vinkin PJ, Bruyn GW eds. Handbook of Clinical Neurology vol. 4. Amsterdam, New York, Oxford: North Holland Publ 1972: 213-222.

105. Opitz JM, ZuRhein GM, Vitale L, et al. The Zellweger syndrome (Cerebro-hepato-renal syndrome). Birth Defects 1969; 5: 144-158.

106. Volpe JJ, Adams RD. Cerebro-hepato-renal syndrome of Zellweger: an inherited disorder of neuronal migration. Acta Neuropathol 1972; 20: 175-198.

107. De Léon GA, Grover WD, Huff DS, et al. Globoid cells, glial nodules, and peculiar fibrillary changes in the cerebro-hepatorenal syndrome of Zellweger. Ann Neurol 1977; 2: 473-484.

108. Evrard P, Caviness Jr VS, Prats-Vinas J, et al. The mechanism of arrest of neuronal migration in the Zellweger malformation: an hypothesis based upon cytoarchitectonic analysis. Acta Neuropathol (Berl) 1978; 41: 109-117.

109. Agamanolis DP, Robinson Jr HB, Timmons GD. Cerebro-hepatorenal syndrome. Report of a case with histochemical and ultrastructural observations. J Neuropathol Exp Neurol 1976; 35: 220-246.

110. Brun A, Gilboa M, Meeuswisse GW, et al. The Zellweger syndrome: subcellular pathology, neuropathology, and the demonstration of pneumocystis carinii pneumonitis in two siblings. Eur J Pediatr 1978; 127: 229-245.

111. Aubourg P, Robain O, Rocchiccioli F, et al. The cerebro-hepatorenal syndrome: lamellar lipid profiles in adrenocortical, hepatic mesencymal, astrocyte cells and increased levels of very long chain fatty acids and phytanic acid in the plasma. J Neurol Sci 1985; 69: 9-25.

112. Goldfischer S, Moore CL, Johnson AA, et al. Peroxisomal and mitochondrial defects in the cerebro-hepato-renal syndrome. Science 1973; 182: 62-64.

113. Moser AE, Singh 1, Brown FR, et al. The cerebrohepatorenal (Zellweger) syndrome. Increased levels and impaired degradation of very-long-chain fatty acids and their use in prenatal diagnosis. New Engl J Med 1984; 310: 1141-1146.

114. Moser HW. Peroxisomal disorders. J Pediatr 1986; 108: 89-91.

115. Schutgens RBH, Heymans HSA, Wanders RJA, et al. Peroxisomal disorders: a newly recognized group of genetic diseases. Eur J Pediatr 1986; 144: 430-444.

116. Brown FR III, McAdams AJ, Cummins JW, et al. Cerebro-hepatorenal (Zellweger) syndrome and neonatal adrenoleukodystrophy: similarities in phenotype and accumulation of very long chain fatty acids. Johns Hopkins Med J 1982; 151: 344-361.

117. Simon T. Über Neubildung von Gehirnsubstanz in Form von Geschwülsen an der Oberfläche der Windungen. Virchow's Arch $1873 ; 58: 310-316$
118. Jacob H. Die feinere Oberflachengestaltung der Hirnwindunge: die Hirnwarzenbildung und die Mikropolygyrie. Z Gesamte Neurol Psychiatrie 1940; 170: 64-68.

119. Morel F, Wildi J. Dysgénésie nodulaire disséminée de l'écorce frontale. Rev Neurol 1952; 87: 251-270.

120. Grcevic N, Robert F. Verrucose dysplasia of the cerebral cortex (dysgénésie nodulaire disséminée of Morel and Wildi). J Neuropathol Exp Neurol 1961; 20: 399-411.

121. Schulze KD, Braak H. Hirnwarzen. Z mikrosk anat Forsch (Leipz) 1978; 92: 609-623.

122. Larroche $\mathrm{J}-\mathrm{Cl}$. Malformations of the CNS. In: Larroche $\mathrm{J}-\mathrm{Cl}$ Developmental Pathology of the Neonate. Amsterdam, London, New York: Excerpta Medica. 1977: 496-498.

123. Robain $\mathrm{O}$, Lyon $\mathrm{G}$. Les micrencéphalies familiaires par malformation cérébrale. Acta Neuropathol 1972; 20: 96-109.

124. Robain O, Deonna T. Pachygria and congenital nephrosis, disorder of migration and neuronal orientation. Acta Neuropathol 1983; 60: 137-141.

125. Sievers J, Mangold M, Berry C, et al. Experimental studies on cerebellar foliation. I. A qualitative morphological analysis of cerebellar fissuration defects after neonatal treatment with 6-OHDA in the rat. J Comp Neurol 1981; 203: 751-769.

126. Della Giustina E, Goffinet AM, Landrieu P, et al. A Golgi study of the brain malformation in Zellweger's cerebro-hepato-renal disease. Acta Neuropathol 1981; 55: 23-28.

127. Barth PG, Uylings HBM, Stam FC. Interhemispheral neuroepithelial (glio-ependymal) cysts, associated with agenesis of the corpus callosum and neocortical maldevelopment. Child's Brain 1984; 11: 312-319.

128. Heschl R. Gehirndefekt und Hydrocephalus. Viertel jahrschrift $f$ d praktishe Heilk 1859; 61: 59-74.

129. Yakovlev PI, Wadsworth RC. Schizencephalies. A study of the congenital clefts in the cerebral mantle. 1. Clefts with fused lips. J Neuropathol Exp Neurol 1946; 5: 116-130.

130. Feld M, Gruner J. Sur deux cas de porencéphalie hémisphérique malformative associée à une agénésie septale. La Presse Médicale 1957; 65: 329-332.

131. Yakovlev PI, Wadsworth RC. Schizencephalies. A study of the congenital clefts in the cerebral mantle. II. Clefts with hydrocephalus and lips separated. J Neuropathol Exp Neurol 1946; 5: 169-206.

132. Barth PG. Prenatal clastic encephalopathies. Clin Neurol Neurosurg 1984;86: 65-75

133. Aicardi J, Goetières F. The sydrome of absence of the septum pellucidum with porencephalies and other developmental defects. Neuropediatrics 1981; 12: 319-329.

134. Friede RL. Dysplasias of cerebellar cortex. In: Friede RL. Developmental Neuropathology. Wien, New York: Springer Verlag, 1975: 326-339.

135. Hart MN, Malamud N, Ellis WG. The Dandy-Walker syndrome. Neurology 1972; 22: 771-780.

136. Joubert M, Eisenring J-J, Preston Robb J, et al. Familial agenesis of the cerebellar vermis. A syndrome of hyperpnea, abnormal eye movements, ataxia and retardation.

137. Boltshauser E, Isler W. Joubert syndrome: episodic hyperpnea, abnormal eye movements, retardation and ataxia, associated with dysplasia of the cerebellar vermis.

138. Friede RL, Boltshauser E. Uncommon syndromes of cerebellar vermis aplasia. 1. Joubert syndrome. Dev Med Child Neurol 1978; 20: 758-763.

139. Harmant-van Rijckevorsel G, Aubert-Tulkens G, Moulin D, et al. Le syndrome de Joubert. Étude clinique et anatomo-pathologique. Rev Neurol 1983; 139: 715-724.

140. Hanaway J, Netsky MG. Heterotopias of the inferior olive: relation to Dandy-Walker malformation and correlation with experimental data. J Neuropathol Exp Neurol 1971; 3: 380-389.

141. Caviness Jr VS, vrard P. Occipital encephalocoele. A pathologic and anatomic analysis. Acta Neuropathol 1975; 32: 245-255.

142. Jellinger $K$, Gross $H$, Kaltenbäck LE, et al. Holoprosencephaly and agenesis of the corpus callosum: frequency of associated malformations. Acta Neuropathol 1981; 55: 1-10.

143. Parrish ML, Roessmann U, Levinsohn MW. Agenesis of the corpus callosum: a study of the frequency of associated malformations. Ann Neurol 1979; 6: 349-354. 
144. Chevrie J-J, Aicardi J. The Aicardi syndrome. In: Pedley TA, Meldrum BS eds. Recent advances in epilepsy vol 3. New York, Edinburgh, London, Melbourne: Churchill Livingstone, 1986: 189-210.

145. Brihaye J, Gillet P, Parmentier R, et al. Agénésie de la commissure associé à un kyste épendymaire. Schweizer Arch Neurol Psychiat 1956; 77: 415-431.

146. Friede RL, Yasargil MG. Supratentorial intracerebral epithelial (ependymal) cysts: review, case reports, and fine structure. J Neurol Neurosurg Psychiat 1977; 40: 127-137.

147. Co-Te P, Dolman CL, Tischler B, et al. Oral-facial-digital syndrome. A case with necropsy findings. Am J Dis Child 1970; 119: $280-283$.

148. Hicks SP. Developmental malformations produced by radiation. A time table of their development. Am J Roetgenol 1953; 69: 272-293.

149. Marin-Padilla M. Structural organization of the cerebral cortex (motor area) in human chromosomal aberrations. A Golgi study. 1. $D_{1}(13-15)$ trisomy, Patau syndrome. Brain Res 1974; 66: 375-391.

150. Marin-Padilla M. Abnormal neuronal differentiation (functional maturation) in mental retardation. Birth Defects 1975; 11(7): 133-153.

151. Terplan KL, Sandberg AA, Aceto Jr T Structural anomalies in the cerebellum in association with trisomy. JAMA 1966; 197: 557-568.

152. Norman RM. Neuropathological findings in trisomies 13-15 and 17-18 with special reference to the cerebellum. Dev Med Child Neurol 1966; 8: 170-177.

153. Terplan KL, Lopez EC, Robinson HB. Histologic structural anomalies in the brain in trisomy 18 syndrome. Am J Dis Child 1970; 119: 223-235.

154. Passarge E, True CW, Sueoka WT, et al. Malformations of the central nervous system in trisomy 18 syndrome. J Pediatr 1966 ; 69: $771-778$

155. Warkany J, Passarge E, Smith LB. Congenital malformations in autosomal trisomy syndromes. Am J Dis Child 1966;112:502-517.

156. Sumi SM. Brain malformations in the trisomy 18 syndrome. Brain 1970; 93 : 821-830.

157. Gottfried M, Lavine L, Roessmann U. Neuropathological findings in Wolf-Hirschhorn (4p-) syndrome. Acta Neuropathol (Berl) 1981; 55: 163-165.

158. Citoler P, Gropp A, Gullotta F. Cytogenetics and pathological observations in the $(4 p-)$ syndrome (Wolf syndrome). Beitr Pathol 1971; 143: 84-96.

159. Leao JC, Bargman GJ, Neu RL, et al. New syndrome associated with partial deletion of short arms of chromosome no 4 . JAMA 1967; 202: 132-135

160. Benda CE. The child with mongolism. New York: Grune \& Stratton. 1960: 78-109.

161. Cherstvoy ED, Lazjuk EI, Ostrovskaya TJ, et al. The SmithLemli-Opitz syndrome. A detailed pathological study as a clue to etiological heterogeneity. Virchows Arch (Path Anat) 1904; 404: 413-425

162. Grummet ML, Bale Jr JF. Brain abnormalities in infants with Potter syndrome (oligohydramnios tetrad). Neurology 1981; 31: 1571-1573.

163. France NE, Crome L, Abraham JM. Pathological features in the De Lange syndrome. Acta Paediat Scand 1969; 58: 470-480.

164. Tucker CC, Finlay SC, Tucker ES, et al. Oral-facial-digital syndrome, with polycystic kidneys and liver: pathological and cytogenetic studies. J Med Genet 1966; 3: 145-147.

165. Majewski F, Lenz W, Pfeiffer RA, et al. Das oro-facio-digitale Syndrom. Z Kinderheilk 1972; 112: 89-112.

166. Rosman NP, Pearce J. The brain in multiple neurofibromatosis (Von Recklinghausen's disease): a suggested neuropathological basis for the associated mental defect. Brain 1967; 90: 829-837.

167. Ferrer, I, Fabregues I, Coll J, et al. Tuberous sclerosis: A Golgi study of a cortical tuber. Clin Neuropathol 1984; 3: 47-51.

168. Ross DL, Liwnicz BH, Chun RWM, et al. Hypomelanosis of Ito (incontinentia pigmenti achromians) - clinicopathologic study: Macrocephaly and grey matter heterotopias. Neurology 1982: 32: 1013-1018.

169. Haberland C, Perou M. Encephalocraniocutaneous lipomatosis. Arch Neurol 1970; 22: 144-155.
170. Choi BH, Kudo M. Abnormal neuronal migration and gliomatosis cerebri in epidermal nevus syndrome. Acta Neuropathol (Berl) 1981; 53: 319-325.

171. Feld M, Gruner J, Heuyer G. Hététerotopies volumineuses et malformations de l'hémisphère droit. Hydrocéphalie avec lésions destructives de l'hemisphère gauche, seules cliniquement traduites. Rev Neurol 1955; 92: 26-35.

172. Bignami A, Palladini G, Zappella M. Unilateral megalencephaly with nerve cell hypertrophy an anatomical and quantitative histochemical study. Brain Res 1968; 9: 103-114.

173. Tjiam AT, Stefanko S, Schenk VWD, et al. Infantile spasms associated with hemihypsarrhythmia and hemimegalencephaly. Dev Med Child Neurol 1978; 20: 779-788.

174. Townsend JJ, Nielsen SL, Malamud N. Unilateral megalencephaly: hamartoma or neoplasm? Neurology 1975; 25: 448-453.

175. Dambska M, Wisniewski K, Sher JH. An autopsy case of hemimegalencephaly. Brain Develop (Tokyo) 1984; 6: 60-64.

176. Manz HJ, Phillips TM, Rowden G, et al. Unilateral megalencephaly, cerebral cortical dysplasia, neuronal hypertrophy and heterotopia cytomorphometric, fluorometric cytochemical and biochemical analysis. Acta Neuropathol 1979; 45: 97-103.

177. Braun JT, Franciosi RA, Mastri AR, et al. Isotretinoin dysmorphic syndrome (letter) Lancet 1984; i: 506-507.

178. Lammer EJ, Chen DT, Hoar RM, et al. Retinoic acid embryopathy. New Engl J Med 1985; 313: 837-840.

179. Hansen LA, Pearl GS. Isotretinoin teratogenicity. Case report with neuropathological findings. Acta Neuropathol 1985; 65: 335-337.

180. Lemoine $P$, Harousseau $H$, Borteyru J, et al. Les enfants de parents alcooliques: anomalies observées. Ouest Med 1968; 25: 476-482.

181. Jones KL, Smith DW. Recognition of the fetal alcohol syndrome in early infancy. Lancet 1973; i: 999-1001.

182. Clarren SK, Alyord Jr EC, Sumi M, et al. Brain malformations related to prenatal exposure to ethanol. J Pediatr 1978; 92: 64-67.

183. Peiffer J, Majewski F, Fischbach $\mathrm{H}$, et al. Alcohol embryo- and fetopathy. Neuropathology of 3 children and 3 fetuses. J Neurol Sci 1979; 41: 125-137.

184. Wisniewski K, Dambska M, Sher J, et al. A clinical neuropathological study of the fetal alcohol syndrome. Neuropediatrics $1983 ; 14$ : 197-201.

185. Ciba foundation symposium 105. Mechanisms of alcohol damage in utero. London: Pitman 1984.

186. Kennedy LA. The pathogenesis of brain abnormalities in the fetal alcohol syndrome: an integrating hypothesis. Teratology 1984; 29: 363-368.

187. Pytkowicz Streissguth A, Landesman-Dwyer S, Martin JC, et al. Teratogenic effects of alcohol in humans and laboratory animals. Science 1980; 209: 353-361.

188. Matsumoto H, Koya G, Takeuchi T. Fetal Minamata disease. A neuropathological study of two cases of intrauterine intoxication by a methylmercury compound. J Neuropathol Exp Neurol 1965; $24: 563-574$.

189. Marsh DO, Myers GY, Clarkson ThW, et al. Fetal methylmercury poisoning: clinical and toxicological data on 29 cases. Ann Neurol 1980; 7: 348-353.

190. Choi BH, Lapham LW, Amin Zaki L, et al. Abnormal neuronal migration, deranged cerebral cortical organization, and diffuse white matter astrocytosis of human fetal brain: a major effect of methylmercury poisoning in utero. J Neuropathol Exp Neurol 1978; 37: 719-733.

191. Choi BH. Mercuri and abnormal development of the fetal brain. In: Dreosti I, Smith R, eds. Neurobiology of the trace elements Vol 1. Clifton, New Yearsey: The Humana Press 1983: 197-235.

192. Choi BH, Cho KH, Lapham LW. Effects of methylmercury on human fetal neurons and astrocytes in vitro: a time-lapse cinematographic phase and electron microscope study. Environm Res 1981; 24: 61-74.

193. Choi BH, Cho KH, Lapham LW. Effects of methylmercury on DNA synthesis of human fetal astrocytes: a radioautographic study. Brain Res 1980; 202: 238-242.

194. Cowen D, Geller LM. Longterm pathological effects of prenatal $X$-irradiation on the central nervous system of the rat. J Neuropathol Exp Neurol 1960; 19: 488-527. 
195. Ebels EJ. Studies on ectopic granule cells in the cerebellar cortex - with a hypothesis as to their etiology and pathogenesis. Acta Neuropathol (Berl) 1972; 21: 117-127.

196. Dekaban AS. Effects of X-radiation on mouse fetus during gestation: emphasis on distribution of cerebral lesions, part II. J Nuclear Med 1969; 10: 68-77.

197. Miller RW. Delayed effects occurring within the first decade after exposure of young individuals to the Hiroshima atomic bomb. Pediatrics 1956; 18: 1-17.

198. Dekaban AS. Abnormalities in children exposed to $x$-radiation during various stages of gestation: tentative timetable of radiation injury to the human fetus. Part I. J Nucl Med 1968; 9 : 476-477.

199. Miller RW, Blot WJ. Small head size after in-utero exposure to atomic radiation. Lancet 1972; ii: 784-787.

200. Miller RW, Mulvihill JJ. Small head size after atomic radiation. Teratology 1976; 14: 355-358.

201. Van Bogaert L, Radermecker MA. Une dysgénésie cérébelleuse chez un enfant du radium. Rev Neurol 1955; 93: 65-82.

202. Shimada M, Abe Y, Yamano T, et al. The pathogenesis of abnormal cytoarchitecture in the cerebral cortex and hippocampus of the mouse treated transplacentally with cytosine arabinoside. Acta Neuropathol 1982; 58; 159-167.
203. Ohno M. Neuroanatomical study of somatomotor cortex in microcephalic mice induced by cytosine arabinoside. Brain Develop (Tokyo) 1984; 6: 528-538.

204. Erdohazi M, Barnes ND, Robinson MJ, et al. Cerebral malformation associated with metabolic disorder. A report of 2 cases. Acta Neuropathol 1976; 36: 315-325.

205. Troost D, van Rossum A, Straks W, et al. Menkes' kinky hair disease. II. A clinicopathological report of three cases. Brain \& Developm 1982; 4: 115-126.

206. Fowler M. A case of arthrogryposis multiplex congenita with lesions in the nervous system. Arch Dis Child 1959; 34: 505-520.

207. Rosman NP, Rebeiz JJ. The cerebral defect and myopathy in myotonic dystrophy. A comparative clinicopathological study. Neurology 1967; 17: 1106-1112.

208. Moerman Ph, Barth PG. Olivo-ponto-cerebellar atrophy with muscular atrophy, and joint contractures of prenatal onset. Virchow's Arch A (in press).

209. Cupo LN, Pyeritz RE, Olson JL, et al. Ehlers-Danlos syndrome with abnormal collagen fibrils, sinus of Valsalva aneurysms, myocardial infarction, panacinar emphysema and cerebral heterotopias. Am J Med 1981; 71: 1051-1058.

210. DeBassio WA, Kemper ThL, Knoefel JE. Coffin-Siris syndrome. Neuropathologic findings. Arch Neurol 1985; 42: 350-353. 